\title{
Estimation of biogenic volatile organic compound (BVOC) emissions in China using WRF-CLM-MEGAN coupled model
}

\author{
Lifei Yin ${ }^{1}$, Zhenying $\mathrm{Xu}^{1}$, Mingxu Liu ${ }^{1}$, Tingting $\mathrm{Xu}^{1,2}$, Tiantian Wang ${ }^{1}$, Wenling Liao ${ }^{1}$, Mengmeng $\mathrm{Li}^{3}$, \\ Xuhui Cai ${ }^{1}$, Ling Kang ${ }^{1}$, Hongsheng Zhang ${ }^{4}$, Yu Song ${ }^{1}$ \\ 5 'State Key Joint Laboratory of Environmental Simulation and Pollution Control, Department of Environmental Science, \\ Peking University, Beijing 100871, China \\ ${ }^{2}$ Environmental College, Chengdu University of Technology, Chengdu 610059, China \\ ${ }^{3}$ School of Atmospheric Sciences, Nanjing University, Nanjing 210000, China \\ ${ }^{4}$ Laboratory for Climate and Ocean-Atmosphere Studies, Department of Atmospheric and Oceanic Sciences, School of Physics, \\ 10 Peking University, Beijing 100871, China
}

Correspondence to: Yu Song (songyu@pku.edu.cn)

\begin{abstract}
Biogenic volatile organic compounds (BVOCs) emitted by terrestrial vegetation significantly influence the atmospheric chemistry and global climate. Previous studies calculated BVOC emissions outside the comprehensive terrestrial ecosystem processes and oversimplified the representation of canopy environments which exert substantial impacts on BVOC

15 emissions. The sophisticated land surface model CLM (Community Land Model) reproduces essential ground and canopy characteristics and can calculate BVOC emissions as a step of integrated biogeochemical processes. In this study, the land surface scheme CLM version4 (CLM4) of WRF (Weather Research and Forecasting model) was used to estimate BVOC emissions in China. Based on highly-resolved meteorological outputs derived from WRF, CLM4 computed real-time physical and biological variables to drive MEGAN (Model of Emissions of Gases and Aerosols from Nature), a BVOC estimation

20 algorithm embedded within biogeochemistry component of CLM4, to calculate plant emission flux. MODIS (Moderate Resolution Imaging Spectroradiometer) land-use data with high resolutions was introduced in WRF to replace the outdated land surface parameters. An emission inventory of isoprene and monoterpenes (including $\alpha$-pinene, $\beta$-pinene, 3 -carene, t- $\beta$ ocimene, limonene, sabinene and myrcene) with high spatiotemporal resolution (12 $\times 12 \mathrm{~km}$, hourly) was established for the year 2018. The annual BVOC emission in China was $14.7 \mathrm{Tg} \mathrm{C}$, in which isoprene contributes about $78.3 \%$ (11.5 Tg C),

25 followed by $\alpha$-pinene $(1.2 \mathrm{Tg} \mathrm{C})$ and $\beta$-pinene $(0.7 \mathrm{Tg} \mathrm{C})$. Due to the strong emission capacity and large areas, broadleaf forests contribute to $76.8 \%$ of total isoprene emission and $72.1 \%$ of monoterpenes emission, respectively. BVOC emissions showed marked seasonal and diurnal patterns with the peak emission occurring in summer and midday. Spatially, high emissions of BVOC were mainly concentrated in southern and northeastern China, as well as the Qinling Mountains in central China, accounting for $91.4 \%$ of national emission. Guangxi, Yunnan and Hunan provinces are significant emitters due to large area

30 of vegetation with high emission rate and favored environmental conditions. The emission estimates are compared to past modeling results, field measurements and further evaluated against top-down isoprene emission estimates. Generally, the coupled mode produced a reasonable simulation in both emission amounts and the spatiotemporal distribution of BVOCs. The
\end{abstract}


https://doi.org/10.5194/bg-2019-458

Preprint. Discussion started: 2 January 2020

(c) Author(s) 2020. CC BY 4.0 License.

(c) (i)

WRF-CLM-MEGAN coupling framework could be further integrated with atmospheric chemistry model to investigate BVOC chemistry and their effects on regional pollution and climate.

\section{1. Introduction}

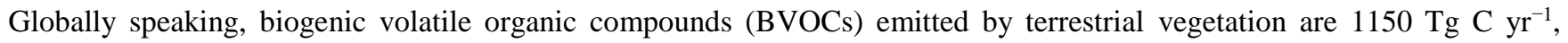
corresponding to about $90 \%$ of the emission total (Guenther et al., 1995). Regionally, although anthropogenic sources are important in urban areas, BVOCs emissions contribute significantly to the total VOC emissions of both urban and rural areas (Benjamin et al., 1997). Many BVOC species are actively involved in the atmospheric chemistry and have substantial impact

40 on tropospheric oxidation, aerosol concentration and the global carbon cycle (Fehsenfeld et al., 1992; Andreae and Crutzen, 1997). BVOCs are therefore a crucial component of the earth system and quantitative estimates of their emissions are required for further exploring their impacts on climate.

It has been demonstrated that a number of ambient and canopy factors modify the capacity of plant to emit BVOC species, such as leaf temperature, leaf phenology, radiation, soil moisture and atmospheric composition (Guenther et al., 2006).

45 However, most studies oversimplified the representation of canopy environments and calculated BVOC emissions as an isolated step outside the whole terrestrial ecosystem processes (Guenther et al., 1995; Guenther et al., 2006; Sindelarova et al., 2014; Müller et al., 2008; Sakulyanontvittaya et al., 2008). For example, BVOC emissions are highly dependent on leaf temperature, while some studies used ambient temperature instead or calculated leaf temperature using independent canopy environment models. Although leaf temperature is primarily dependent on ambient temperature, it is also influenced by other ecological conditions that cannot be reproduced well in canopy environment models, such as humidity, evapotranspiration and soil moisture (Guenther et al., 2006). Additionally, using the dominant vegetation type in a grid for simulation, many studies failed to consider the ecological differences among vegetation types within a grid cell.

Only a few studies coupled BVOC emissions within land surface process. Levis et al. (2003) incorporated BVOC algorithms within Community Land Model version 2 (CLM2) as one step toward integrating biogeochemical processes in the land surface parameterizations. CLM2 formalizes and quantifies concepts of ecological climatology with representations of essential land and vegetation processes, which is better to drive BVOC algorithms. However, CLM2 is originally coupled within earth climate models, the resolution of which ranges over hundreds of kilometers and is too coarse to simulate regional weather and climate accurately (Bonan et al., 2002; Jin et al., 2010).

CLM4 (denoted hereafter as CLM) was coupled and released with the Weather Research and Forecasting model (WRF), a 60 mesoscale numerical model designed to simulate or predict regional weather and climate, since version 3.5 as one of the land surface scheme options. The coupled model made it possible to estimate regional BVOC emissions within a comprehensive ecological climatology framework. CLM consists of components related to land biogeophysics, hydrologic cycle, biogeochemistry, human dimensions and ecosystem dynamics. A wide range of ecological and physiological processes which influence BVOC emissions are simulated in different component, providing real-time variables to drive BVOC algorithms. 
https://doi.org/10.5194/bg-2019-458

Preprint. Discussion started: 2 January 2020

(c) Author(s) 2020. CC BY 4.0 License.

(c) (i)

65 For instance, leaf temperature and canopy solar radiation are calculated at every time step in the biogeophysics module. The hydrologic cycle includes representations of soil moisture, transpiration and canopy evaporation, which are directly linked to the biogeophysics and also affect leaf temperature simulations. Moreover, as a sophisticated ecological framework, CLM also characterizes other land surface processes that influence BVOC emissions but have not been parameterized in current BVOC algorithms, such as photosynthesis and stomatal conductance (Oleson et al., 2010; Guenther et al., 2000). Through the comprehensive parameterization of canopy and soil processes, CLM can provide more reasonable canopy environment variables for regional BVOC estimates. However, the coupled mode has seldom been used to estimate regional BVOC emissions.

Large areas of China are covered by various vegetation. Due to the effects of afforestation and forest management, observed leaf area index (LAI) in eastern China experienced persistent increase over the past three decades (Zhu et al., 2016), enhancing

75 BVOC emissions. In recent decades, studies have been conducted in China to estimate national or regional BVOC emissions which reported a wide emission range of 4.1-23.4 $\mathrm{Tg} \mathrm{C} \mathrm{yr}^{-1}$ for isoprene and 1.8-5.6 $\mathrm{Tg} \mathrm{C} \mathrm{yr}^{-1}$ for monoterpenes on the national level (Guenther et al., 1995; Klinger et al., 2002; Guenther et al., 2006; Tie et al., 2006; Fu and Liao, 2012; Li et al., 2013; Stavrakou et al., 2014). However, none of these studies estimated emissions within a comprehensive land surface model, leading to large inaccuracies in calculation process and estimations.

80 In this study, we aimed to use a more reasonable way to estimate BVOC emissions in China. The WRF-CLM coupling framework was used to drive the Model of Emissions of Gases and Aerosols from Nature (MEGAN), the BVOC emission model embedded within CLM land surface scheme. The BVOC emissions were calculated within land surface process using real-time variables provided by CLM. CLM allowed for multiple plant types within a grid cell, thereby accounting for subgrid ecological differences among vegetation types. Moreover, the atmospheric chemistry and transport module could be

85 further coupled with the present WRF-CLM framework to achieve a synchronous coupling of emissions, transport and chemistry processes. The dynamic vegetation scheme in CLM could allow WRF to predict future variations in regional vegetation cover and BVOC emissions (Levis et al., 2003; Lawrence et al., 2011). Because we aimed to evaluate the ability of the coupling framework to calculate regional BVOC emissions and develop an inventory for China, the chemistry and dynamic vegetation module was not considered in this study. Highly-resolved Moderate Resolution Imaging Spectroradiometer

90 (MODIS) land cover and LAI datasets were introduced into WRF to replace outdated land surface parameters. Two primary classes of BVOCs, isoprene $\left(\mathrm{C}_{5} \mathrm{H}_{8}\right)$ and monoterpenes $\left(\mathrm{C}_{10} \mathrm{H}_{16}\right)$ (including $\alpha$-pinene, $\beta$-pinene, 3 -carene, t- $\beta$-ocimene, limonene, sabinene and myrcene), were considered in this study.

\section{Methods and data}

\subsection{WRF-CLM-MEGAN coupled model}

95 The CLM was coupled and released with WRF since version 3.5 as one of the land surface scheme options. CLM includes 5 layers for snow, 15 layers for soil and 1 layer for vegetation and has been shown to be accurate in describing soil and vegetation 
https://doi.org/10.5194/bg-2019-458

Preprint. Discussion started: 2 January 2020

(c) Author(s) 2020. CC BY 4.0 License.

(c) (i)

processes (Bonan et al., 2002; Zeng et al., 2002; Lawrence et al., 2011). In the coupling framework, the BVOC emissions were calculated as part of biogeochemistry within terrestrial ecosystem parameterization. Using highly-resolved meteorological fields provided by WRF, CLM represented comprehensive ecological and physiological processes and computed real-time environmental factors to drive MEGAN to calculate real-time emission response. Detailed information and algorithms of CLM can be found in Oleson et al. (2010).

MEGAN is a modeling framework for estimation fluxes of biogenic compounds from terrestrial ecosystems using mechanistic algorithms to account for the major known process controlling biogenic emissions. MEGAN estimates emissions $\left(F_{i}, \mu \mathrm{g} \mathrm{C} \mathrm{m^{-2 }}\right.$ ground area $\mathrm{h}^{-1}$ ) of BVOC species $i$ according to

$F_{i}=\gamma_{i} \times \sum \varepsilon_{i, j} \times \chi_{j}$

Where $\varepsilon_{i, j}\left(\mu \mathrm{g} \mathrm{C} \mathrm{m}^{-2} \mathrm{~h}^{-1}\right)$ is the emission factor $(\mathrm{EF})$ at standard conditions for PFT $j$ with fraction coverage $\chi_{i, j}$. PFT-specific EFs of individual species were determined based on previous studies or literature (Klinger et al., 2002; Bai et al., 2006; Tie et al., 2006; Guenther et al., 2006; Wang et al., 2011; Fu and Liao, 2012; Guenther et al., 2012). Table 1 summarizes the EFs for each vegetation type used in this study.

110 The emission activity factor for each compound $\left(\gamma_{i}\right)$ accounts for emission response to light, leaf temperature, leaf age, soil moisture, LAI and $\mathrm{CO}_{2}$ inhibition. Therein, the canopy solar radiation and leaf temperature was calculated in the biogeophysical component of CLM, and the soil moisture was represented in hydrologic cycle module. The interactions between each component were also taken into account. LAI could be calculated by vegetation dynamics in CLM, which is beyond the scope of this study; therefore, we used satellite-observed LAI data for calculation. In this study, the influence of

$115 \mathrm{CO}_{2}$ concentration was neglected, so that $\gamma_{\mathrm{C}}$ for all compounds was set to 1 . The details of the algorithms could be found in Guenther et al. (2012).

In this study, the simulations with the WRF version 4 were performed on a domain at $12 \mathrm{~km}$ horizontal resolution covering China and its surrounding areas with $420 \times 380$ cells in the horizontal direction and 35 layers in the vertical direction, extending from the surface to $50 \mathrm{hPa}$. The initial meteorological fields and boundary conditions were from the $6 \mathrm{~h}$ NCEP (National

120 Centers for Environmental Prediction) global final analysis with a $1^{\circ} \times 1^{\circ}$ spatial resolution. The simulation was conducted for the year 2018, and each run covered 31 days in order to account for the long-term influence of meteorological conditions (temperature and solar radiation) on plant emission ability.

\subsection{Improvement of land surface parameters in WRF and CLM}

The standard WRF initial static field uses the 24-category United States Geological Survey (USGS) global 1 km land cover map derived from the monthly Advanced Very High Resolution Radiometer (AVHRR) observation, which is based on 1-year data from April 1992 to March 1993. This data could not represent the real surface features due to the rapid land cover changes. In this study, MODIS datasets of land cover (MCD12Q1) for the year 2016 and water mask (MOD44W) for the year 2015, both with a resolution of $500 \mathrm{~m}$, were used to obtain a new land use map by mapping the 17 MODIS land-use categories 
https://doi.org/10.5194/bg-2019-458

Preprint. Discussion started: 2 January 2020

(c) Author(s) 2020. CC BY 4.0 License.

(c) (i)

defined by the International Geosphere Biosphere Program (IGBP) onto the outdated 24 USGS categories. The coverage fraction of each land use type in each grid cell was also calculated based on the new land use map. The significantly improved model performance resulted by replacing land cover data has been revealed in Li et al. (2014b) and Li et al. (2015).

Default CLM prescribes the PFTs composition and abundance of each land cover type of USGS, leading to a geographicalinvariant plant distribution that may not match the actual situation (Oleson et al., 2010). We modified the default setting to represent the sub-grid surface heterogeneity with the composition and fraction of $500 \mathrm{~m}$-resolved land cover data within the $12 \mathrm{~km}$-resolved model grid. The 12 vegetation categories in IGBP were converted to 7 PFTs in CLM scheme. Table 2 illustrates the conversion of MODIS land cover into USGS and PFTs. The mixed forests and woody savannas in MODIS data were considered as broadleaf deciduous trees and the savannas in MODIS were identified as shrubs. The conversion was determined according to vegetation distributions presented in three land cover datasets, including GlobeLand30 (Chen et al., 2017), 30mresolution Forest map for China (Li et al., 2014a) and the Vegetation Atlas of China (Li et al., 2013). The spatial distribution of seven major PFTs was shown in Fig. 1 (the small island in the South China Sea are not included).

LAI data used in default CLM scheme are updated daily by linearly interpolating between prescribed monthly values. In this study, the MODIS LAI data derived from MCD15A2H version 6 with a spatial resolution of $500 \mathrm{~m}$ and temporal resolution of 8 days was introduced in CLM to replace default values and drive MEGAN to estimate the influence of LAI and leaf age on BVOC emission capacities. Instead of using a grid-averaged LAI value for all vegetation types, the PFT-specific LAI was averaged over the fraction of land area covered by the particular PFT within the grid cell.

In the origin CLM land surface scheme, the calculation of average temperature and radiation of the past days, which is required by MEGAN algorithm, exhibited errors and was commented out. We modified this part of the code in order to consider the long-term influence of meteorological conditions on emission abilities.

\section{Results and discussions}

\subsection{Evaluation of WRF output}

The observed surface temperature of 362 sites in China provided by the National Climatic Data Center (NCDC), available with a temporal resolution of an hour, and observed daily total radiation data of 100 sites in China downloaded from the National Meteorological Information Center (https://data.cma.cn/) were used to evaluate the simulation performance of the temperature at $2 \mathrm{~m}$ height (T2) and the downward shortwave radiation (SWDOWN) of WRF. The statistical analyses for four seasons are displayed in Table 3. The mean error (ME), mean bias (MB), correlation coefficient $(r)$ and root-mean-square error (RMSE) of station-averaged hourly T2 series are $1.70,-0.52,0.98,2.51^{\circ} \mathrm{C}$, respectively. The $r$ value in summer $(0.90)$ is relatively lower than those in spring (0.95), autumn (0.96), winter (0.97), and the simulation shows slight cooling bias in spring, autumn and winter. The ME, MB, $r$, RMSE values of the whole-year SWDOWN series are 71.01, 69.82, 0.86 and $71.11 \mathrm{~W}$ $\mathrm{m}^{-2}$, and the simulation shows overestimation of $85.37,86.05,55.55$ and $52.32 \mathrm{~W} \mathrm{~m}^{-2}$ in spring, summer, autumn and winter, respectively. 
https://doi.org/10.5194/bg-2019-458

Preprint. Discussion started: 2 January 2020

(c) Author(s) 2020. CC BY 4.0 License.

(c) (i)

The seasonal variation and spatial distributions of simulated seasonally average T2 and SWDOWN are presented in Fig. 2 (excluding small islands in the South China Sea). In general, the simulations of WRF-CLM reproduce the temporal and spatial patterns of T2 and SWDOWN. The highest T2 and SWDOWN values occur in summer, followed by spring and autumn, and then winter. The temperature generally decreases from the south to the north, consistent with terrain height and latitude. The spatial characteristics of solar radiation are influenced by latitude, altitude and climate change. Overall, the solar radiation reaches a high value near the Tibetan Plateau, and low values occur around the Sichuan Basin. The WRF model can reasonably simulate the spatial pattern of the solar radiation, whereas the amounts are higher than observations, as illustrated in Table 3 . The overestimation could be attributed to ignoring radiation effect of aerosols in the model (Markovic et al., 2008; Wild, 2008). Besides, the excess downward solar radiation is a discrepancy that has been found in many other studies, suggesting that the WRF model has some deficiencies independent of the land surface model that lead to the systematic overestimation (Lu and Kueppers, 2012). Generally, Table 3 as well as Fig. 2 indicate relatively good simulation among most of sites; therefore, the meteorological conditions simulated by WRF-CLM are desirable for driving MEGAN.

\subsection{BVOC emission budgets}

Hourly emissions of 8 chemical species emitted from biogenic sources including isoprene, $\alpha$-pinene, $\beta$-pinene, 3 -carene, t- $\beta$ ocimene, limonene, sabinene and myrcene were calculated by WRF-CLM-MEGAN model on a $12 \mathrm{~km} \times 12 \mathrm{~km}$ grid for the year 2018. In the following section, all the results are measured as carbon weights of the constituent compounds, unless stated otherwise.

The China land area can be subdivided into six regions as shown in Fig. S1 (the small island in the South China Sea are not included). Regional and national annual totals of individual species are listed in Table 4. The annual amount emitted for all listed BVOCs reaches $14.7 \mathrm{Tg} \mathrm{C} \mathrm{yr}^{-1}$ with isoprene accounting for $78.3 \%$ (11.5 Tg) and sum of monoterpenes for $21.7 \%$ (3.2 $\mathrm{Tg}$ ). Regarding the relative contributions of species considered in the sum of monoterpenes, $\alpha$-pinene (1.2 $\mathrm{Tg}$ ) is the largest contributor, accounting for about $8.4 \%$ of the total BVOC emissions and $38.8 \%$ of the total monoterpenes emissions. The other main contributors are $\beta$-pinene $(0.7 \mathrm{Tg})$ and limonene $(0.4 \mathrm{Tg})$, which are responsible for $21.6 \%$ and $13.3 \%$ of the annual monoterpenes emission, respectively. The emissions of other monoterpene species are negligible: $\mathrm{t}-\beta$-ocimene $(0.3 \mathrm{Tg})$,

185 3-carene $(0.2 \mathrm{Tg})$, sabinene $(0.2 \mathrm{Tg})$, myrcene $(0.1 \mathrm{Tg})$.

The emission ability of BVOC varies substantially between and within PFTs (Guenther et al., 2006). The field measurements indicated that broadleaf forests (especially Quercus, Populus and Eucalyptus) and shrubs have high isoprene emission capacities, while conifer species (especially Pinus and Picea) favor terpene emission over isoprene. Crops and grass are considered to have low BVOC emitting capacities (Guenther, 2013; Bai et al., 2016; Klinger et al., 2002; Bai et al., 2015). The relative contribution of each considered PFT to the national BVOC totals is shown in Table 5.

For both isoprene and monoterpenes, the predominant sources of emissions are the broadleaf deciduous forests with a relative contribution of $64.5 \%$ and $60.6 \%$, respectively. Shrubs rank second of the emission contribution, accounting for $19.9 \%$ of total BVOC emissions, followed by broadleaf evergreen trees (12.1\%). In sum, broadleaf trees are responsible for $76.8 \%$ of 
https://doi.org/10.5194/bg-2019-458

Preprint. Discussion started: 2 January 2020

(c) Author(s) 2020. CC BY 4.0 License.

(c) (i)

isoprene emission and $72.1 \%$ of monoterpenes emission, respectively. The contribution of needleleaf forests to monoterpenes emission $(6.4 \%)$ is higher than that to isoprene $(0.5 \%)$, in agreement with the in situ experiment results. Grass and Crop are minor BVOC sources with only $1.3 \%$ of total isoprene emission and $1.1 \%$ of monoterpene emission, respectively.

\subsection{Spatial distribution of BVOC emission budget}

As described in section 2.1, the spatial variation of BVOC emissions is determined by the distribution of tree species and meteorological conditions.

200 The spatial distributions of annual emissions of isoprene and monoterpenes are displayed in Fig.3 (excluding small islands in the South China Sea). As shown in Table 4 and Fig.3, BVOCs are mainly emitted in southwestern China, which contributes to about $35.4 \%$ to the national total, followed by central China (25.6\%) and southeastern and northeastern regions contributing with $20.1 \%$ and $10.4 \%$, respectively. Less than $10 \%$ of national BVOCs are emitted in the northern and northwestern China. The southern and northeastern regions of China, as well as the Qinling Mountains in central China exhibit high emission budgets, accounting for $91.3 \%$ of the national isoprene emission and $91.8 \%$ of the monoterpenes emission. The top-ranking isoprene contributor is Guangxi, with approximately $1.3 \mathrm{Tg}$ C emitted yearly, followed by Yunnan and Hunan (both $1.1 \mathrm{Tg}$ ). According to Fig.1 and the survey results from the Plant Research Institute, these areas are covered by vegetation species with high emission capacity of isoprene (broadleaf forests, shrub) or monoterpenes (coniferous forest). Northeast China is primarily covered by deciduous coniferous forests (mainly Larix gmelini) and deciduous broadleaf forests (mainly Quercus mongolica,

210 Tilia Mongolia and Betula platyphylla). Large areas of evergreen coniferous forests (mainly Pinus massoniana and Cunninghamia lanceolata) and shrubs are found in Southeast China, and the main plant genera in Southwest China are evergreen tree species, including evergreen broadleaf forests (e.g. Quercus aquifolioides), evergreen coniferous forests (Picea likiangensis var.balfouriana and Pinus yunnanensis) and shrubs. The Qinling Mountains are covered by large areas of deciduous broadleaf forests (mainly Quercus variabilis and Quercus liaotungensis).

215 However, the results also illustrate a contradiction between the high plant coverage and the relatively low isoprene emission in Sichuan Province. With abundant broadleaf deciduous tree and shrub, Sichuan emits $0.7 \mathrm{Tg}$ C annually, which could be attributed to the low temperatures in the west of Sichuan and low solar radiation in the east of Sichuan (Fig. 2). Similarly, the northeastern China, covered by large areas of broadleaf deciduous forests, shows lower emission amounts (9.2\% of isoprene and $14.5 \%$ of monoterpenes) when compared with the Qinling mountains (26.4\% of isoprene and $22.5 \%$ of monoterpenes).

220 This results could be partly explained by the higher latitude that leads to lower temperature and light intensity in the northeastern China (as shown in Fig. 2) and thus reduces the vegetation ability of producing and emitting BVOC.

The regions covered by large area of crop or grassland, such as the North China Plain and Inner Mongolia, release extremely small amount of BVOC due to the low BVOC emitting capacities of crop and grass. 
https://doi.org/10.5194/bg-2019-458

Preprint. Discussion started: 2 January 2020

(c) Author(s) 2020. CC BY 4.0 License.

(c) (i)

\subsection{Temporal variations in BVOC emissions}

BVOC emissions exhibit strong seasonal variation as a consequence of the substantial differences in monthly environmental conditions, such as temperature, solar radiation and plant water stress. The average seasonal emission fluxes of isoprene and monoterpenes are presented in Figs. 4 and 5 (the small island in the South China Sea are not included), and the temporal profile of national monthly emissions of individual species is presented in Fig. 6. Because of the highest light intensities, temperatures and plant biomass density, the emission rates peak in summer (from June to August) and around $55.1 \%(8.1 \mathrm{Tg} \mathrm{C})$ of the total annual BVOC emissions are released during this period. In spring (from March to May), deciduous trees started to develop leaves and the increasing foliage density enhanced the BVOC emission flux. Moreover, less precipitation in spring resulted in inadequate soil moisture, which could decrease BVOC emission rates (Pegoraro et al., 2004). From September, emissions decrease rapidly because of the loss of biomass density and decreasing ambient temperature and solar radiation intensity. The total emission in autumn (from September to November, $3.5 \mathrm{Tg}$ ) is slightly higher than that in Spring (2.7 Tg), which could be explained by the higher leaf area (as shown in Fig.2) and a corresponding higher emission capacity in autumn. In addition, taking the long-term influence of temperature and solar radiation into account also contributes to a higher emission in autumn while a lower value in spring. In winter, ambient temperature and radiation intensity reaches the lowest value for the year and results in the lowest emission rates. Besides, as more than $90 \%$ of BVOC emissions are produced and emitted from plant foliage, extremely low foliage density in winter leads to negligible BVOC emissions $(0.4 \mathrm{Tg})$.

Aside from being seasonal, the natural emissions exhibit an obvious diurnal cyclical pattern. The diurnal variations of temperature, solar radiation and emission of isoprene and monoterpenes in summer are shown in Fig. 7. Simulated emissions of isoprene and monoterpene rise rapidly in the morning and reach the peak in the afternoon (13:00 14:00, Beijing Time), as a consequence of the increasing plant metabolism at times with relatively high light intensity and temperature, which lead to higher activity of BVOC production. Emissions of monoterpenes are temperature dependent but not highly dependent on light while isoprene emissions are strong light-dependent. As a result, monoterpene emissions maintain a relatively high level during the night while isoprene emissions cease at nighttime. However, since specific light-dependent factors for various compounds, including monoterpenes, are used in the model, the magnitude of the diurnal variation of monoterpene emissions is larger than that estimated by past studies that considered monoterpene emissions as solely temperature dependent (Tie et al., 2006).

\subsection{Comparisons with field measurements and previous budgets estimations}

250 There are little intensive measurements of BVOC fluxes in China due to the difficulties in techniques of large-scale and longterm measurements. Hence, we just evaluate the inventory against limited results of canopy-scale measurements conducted at different sites in China.

Using eddy covariance technique, Baker et al. (2005) measured isoprene fluxes in Xishuangbanna, Yunnan Province $\left(21.92^{\circ} \mathrm{N}\right.$, $101.27^{\circ} \mathrm{E}$ ) and the daytime-averaged fluxes were found to be $1 \mathrm{mg} \mathrm{C} \mathrm{m}^{-2} \mathrm{~h}^{-1}$ during the wet season (July 2002). Model results 
https://doi.org/10.5194/bg-2019-458

Preprint. Discussion started: 2 January 2020

(c) Author(s) 2020. CC BY 4.0 License.

(c) (i)

factor of 2. A field measurement was conducted at Dinghushan $\left(23.17^{\circ} \mathrm{N}, 112.53^{\circ} \mathrm{E}\right)$, Guangdong Province using the Relaxed Eddy Accumulation (REA) technique to quantify BVOC emission flux from a subtropical evergreen mixed forest in fall 2010 (Situ et al., 2013). As a result, the isoprene emission fluxes ranged between 0.002 and $0.215 \mathrm{mg} \mathrm{m}^{-2} \mathrm{~h}^{-1}$ and monoterpenes fluxes ranged between 0.063 and $0.313 \mathrm{mg} \mathrm{m}^{-2} \mathrm{~h}^{-1}$. Model simulations show that the average emission fluxes of daytime in autumn were $0.351 \mathrm{mg} \mathrm{m}^{-2} \mathrm{~h}^{-1}$ for isoprene and $0.052 \mathrm{mg} \mathrm{m}^{-2} \mathrm{~h}^{-1}$ for monoterpenes, which are close to the observed data range.

Based on REA technique, emissions of isoprene and monoterpenes of a temperate forest in Changbai Mountain $\left(42.4^{\circ} \mathrm{N}\right.$, $128.1^{\circ} \mathrm{E}$ ) were measured during the summer seasons (June, July, August, September) in 2010 and 2011 (Bai et al., 2015). The mean isoprene emission flux was $0.889 \mathrm{mg} \mathrm{m}^{-2} \mathrm{~h}^{-1}$ and the mean total monoterpene emission flux was $0.143 \mathrm{mg} \mathrm{m}^{-2} \mathrm{~h}^{-1}$, and our results estimated emission fluxes of 2.032 for isoprene and 0.453 for monoterpene. Using the same method, Bai et al. (2016) measured emissions from a bamboo (Phyllostachys violascenes) plantation in Zhejiang Province $\left(30.3^{\circ} \mathrm{N}, 119.57^{\circ} \mathrm{E}\right)$ and the isoprene emission flux averaged in July and August was $1.91 \mathrm{mg} \mathrm{m}^{-2} \mathrm{~h}^{-1}$, which is close to our estimated value of 2.03 $\mathrm{mg} \mathrm{m}^{-2} \mathrm{~h}^{-1}$.

Generally, the agreement of our simulated emissions with most observations is satisfactory, because the meteorological conditions at the specific times and sites can significantly differ from that of the simulation period, and some special conditions (such as severe drought) at the site may not be reproduced well by the model (Stavrakou et al., 2014). In addition, the measurement technique may underestimate the BVOC flux. For example, Bowling et al. (1999) suggested that mixing of samples would lead to an underestimated flux. Overall, the field measurements of BVOC flux can be very different from the model estimate, and more field experiments are needed to accurately quantify the BVOC emission fluxes and to further evaluate the model performance.

Because of the differences in algorithms and input data applied, our results may differ greatly from previous budget estimations. As illustrated in Table 6, the annual emission budgets estimated by this study fall in the range of past studies and is close to results of Guenther et al. (2006) and Fu and Liao (2012), while lower than the result of Guenther et al. (1995) by $31.3 \%$ and higher than that of Klinger et al. (2002) by $93.4 \%$, which were all based on the outdated G95 algorithms (Guenther et al., 1995). This discrepancy between results of Klinger et al. (2002) and this study is mainly due to the differences in vegetation distribution and Klinger et al. (2002) can only reflect the natural emission level of vegetation during the last decade. Li et al. (2012) suggested that the use of outdated USGS land-use distribution in Tie et al. (2006) should be responsible for the underestimation of BVOC emissions. Considering the same land use and LAI datasets used for calculation, the discrepancy between results of Fu and Liao (2012) and this study could be attributed to the differences in algorithms. Similar to most past studies, Fu and Liao (2012) considered only one dominant land cover type within a grid cell and applied grid-averaged LAI for calculation, ignoring the extreme differences in emission capacities between tree species. The use of average LAI might overestimate emissions from plants with small leaf area (e.g., grass, coniferous trees) and underestimate emissions from plants with large leaf area (broadleaf trees, shrub). The use of WRF-CLM in this study accounted for vegetation diversity within grid can produce a more reasonable emission estimates. 
https://doi.org/10.5194/bg-2019-458

Preprint. Discussion started: 2 January 2020

(c) Author(s) 2020. CC BY 4.0 License.

(c) (i)

290 Formaldehyde (HCHO), as a major intermediate product in the degradation of isoprene in the atmosphere, has been widely used as a proxy for estimates isoprene emissions. Fu et al. (2007) used a continuous 6-year record (1996-2001) of Global Ozone Monitoring Experiment (GOME) HCHO columns and made a top-down estimates for isoprene as $12.7 \mathrm{Tg} \mathrm{yr}^{-1}$ in China, which is comparable to the our model outputs. However, Stavrakou et al. (2014) inferred isoprene emissions by inversion of GOME-2 HCHO columns and the satellite-derived emissions were found to decrease from 8.6 Tg in 2007 to $6.5 \mathrm{Tg}$ in 2012, lower than emissions in this study by $33.7 \%-76.9 \%$. Aside from the influence of difference meteorological conditions and land cover changes during the past years, the reliability of satellite-based constraints also needs to be improved because that the $\mathrm{HCHO}$ is affected by non-isoprene sources plus uncertainty and spatial smearing in isoprene-formaldehyde relationship (Fu et al., 2019).

\section{Uncertainty}

300 Uncertainties in both model inputs and modeling framework could affect the accuracy of estimation. There are three main inputs to the MEGAN: land cover data (vegetation distribution and LAI), emission factors and meteorological data.

The basal emission factors have been identified as the most important uncertainty source (Situ et al., 2014; Wang et al., 2016; Zheng et al., 2010). We used the localized emission factors based on BVOC emission rate measurements from previous studies. However, local studies measuring the basal emission rate of BVOCs cover only a small fraction of tree species. Further measurements for emission rates of plantations in China are required. In addition, since the PFT-specific emission rates are assigned to each grid according to the land cover data, an accurate vegetation distribution map with higher spatial resolution and more detailed classification of tree species is expected to improve the accuracy of emission rate assignment. Wang et al. (2011) investigated the impact of meteorological conditions and indicated that the simulation bias of temperature and solar radiation resulted in $26.7 \%$ and $50.7 \%$ uncertainties to isoprene, respectively. Wang et al. (2018) adopted three LAI datasets

310 to study the effect of the LAI input on BVOC emissions and indicated that the discrepancies between different LAI inputs do not obviously affect the estimates, similar to the results of Zheng et al. (2010).

The emission algorithm is also an important source of uncertainty. Although the dominant processes controlling BVOC emission have been considered in MEGAN algorithm, substantial uncertainties remain. For example, the influence of concentration of $\mathrm{CO}_{2}$ and ozone has not been quantified in this study. It has been indicated that the empirical coefficients used

315 for computation contribute to uncertainties in estimates as well (Zheng et al., 2010; Situ et al., 2014).

\section{Conclusion}

This study estimated the emission budgets and spatial-temporal patterns of BVOC in China in 2018 using the WRF-CLMMEGAN modeling system. CLM characterizes comprehensive land surface processes including biogeophysics, biogeochemistry, hydrologic cycle and ecosystem dynamics, which are strongly linked to the BVOC emissions. Through the 
https://doi.org/10.5194/bg-2019-458

Preprint. Discussion started: 2 January 2020

(c) Author(s) 2020. CC BY 4.0 License.

(c) (i)

320 parameterization of these ecological and physiological processes, CLM can provide more reasonable canopy environment variables required by BVOC algorithms. Highly-resolved MODIS land-use data were introduced in WRF to replace the outdated land surface parameters and improve model performance.

Isoprene $\left(\mathrm{C}_{5} \mathrm{H}_{8}\right)$ and monoterpenes $\left(\mathrm{C}_{10} \mathrm{H}_{16}\right)$ (including $\alpha$-pinene, $\beta$-pinene, 3 -carene, $\mathrm{t}$ - $\beta$-ocimene, limonene, sabinene and myrcene) emissions were calculated and analyzed. The total amount of BVOCs emitted in China was estimated to be $14.7 \mathrm{Tg}$

$325 \mathrm{C} \mathrm{yr}^{-1}$, with isoprene and monoterpenes accounting for $78.3 \%$ and $21.7 \%$ of the totals, respectively. Spatially, the hot spots of BVOC emissions includes the southern and northeastern regions of China, as well as Qinling Mountains in central China, owing to the dense plant cover in these regions. Due to the strong emission capacity and large coverage, broadleaf deciduous forest has been identified as dominate emitter of isoprene and monoterpenes, accounting for $64.5 \%$ of total isoprene emissions and $60.6 \%$ of total monoterpenes emissions, respectively. Coniferous trees were responsible $5.6 \%$ monoterpenes, while emitted little isoprene $(0.5 \%)$. As the temperature and solar radiation varied substantially, BVOC emissions correspondingly exhibited significant seasonal variability: the summer time contributed $55.1 \%$ of the total emissions while the winter only contributed $2.9 \%$. The diurnal variation mainly follows the solar radiation and temperature pattern and daily maximum occurs at about 13:00 14:00 (Beijing Time).

Our results are at the upper end of values presented in previous modeling estimates, which can be partly explained by the incorporation of CLM, which provides more reasonable canopy characterizations. Comparison of earlier studies on national isoprene estimates has shown that isoprene emissions can vary within a factor of 2 . The simulated variations in spatial and temporal patterns are in excellent agreement with earlier studies.

Results of this study are compared to flux measurements at four sites located in the southwestern, southeastern and northeastern China. The comparison shows that the model tends to overestimate the isoprene fluxes by $6.2 \% \sim 128.6 \%$ and monoterpene

340 fluxes by a factor of 2 . The different meteorological conditions at the specific times and sites that measurements were taken are different from and that of the simulation period can lead to substantial discrepancy between observations and simulations. Moreover, mechanical failures in field measurements may result in underestimation of the BVOC flux. Two top-down results estimated by inverse modeling using formaldehyde as a proxy for VOC emissions are used to evaluate our results and the discrepancy ranges between $-10.4 \%$ and $76.9 \%$. Although using a model to estimate BVOC emissions is a key study approach,

345 additional ambient observed data are needed to further evaluate the model performance. On the basis of this study, we can further couple this framework with chemistry module to investigate the role of BVOCs in regional and global atmosphere chemistry, carbon cycle and climate change.

Data availability. MCD12Q1 product can be freely accessed at https://doi.org/10.5067/MODIS/MCD12Q1.006. MOD44W data can be download from https://doi.org/10.5067/MODIS/MOD44W.006. MCD15A2H data can be found at 
https://doi.org/10.5194/bg-2019-458

Preprint. Discussion started: 2 January 2020

(C) Author(s) 2020. CC BY 4.0 License.

(c) (1)

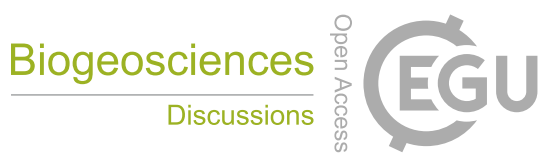

Author contributions. This work was designed by YS, XC, LK and HZ, and performed by LY, ZX, ML, TX, TW, WL and ML. LY and YS led the writing of the papers and prepared the figures with contributions from all co-authors.

Competing interests. The authors declare that they have no conflict of interest.

Acknowledgements. The MODIS land cover data (MCD12Q1), water mask data (MOD44W) and leaf are index product 355 (MCD15A2H) were provided by Land Process Distributed Active Archive Center (LPDAAC), USA. This work was supported by the National Natural Science Foundation of China (NSFC) $(41675142,91644212)$. 
https://doi.org/10.5194/bg-2019-458

Preprint. Discussion started: 2 January 2020

(c) Author(s) 2020. CC BY 4.0 License.

\section{References}

Andreae, M. O., and Crutzen, P. J.: Atmospheric Aerosols: Biogeochemical Sources and Role in Atmospheric Chemistry, Science, 276, 1052, 10.1126/science.276.5315.1052, 1997.

Bai, J., Baker, B., Liang, B., Greenberg, J., and Guenther, A.: Isoprene and monoterpene emissions from an Inner Mongolia grassland, Atmospheric Environment, 40, 5753-5758, https://doi.org/10.1016/j.atmosenv.2006.05.019, 2006.

Bai, J., Guenther, A., Turnipseed, A., and Duhl, T.: Seasonal and interannual variations in whole-ecosystem isoprene and monoterpene emissions from a temperate mixed forest in Northern China, Atmospheric Pollution Research, 6, 696-707, https://doi.org/10.5094/APR.2015.078, 2015.

Bai, J., Guenther, A., Turnipseed, A., Duhl, T., Yu, S., and Wang, B.: Seasonal variations in whole-ecosystem BVOC emissions from a subtropical bamboo plantation in China, Atmospheric Environment, 124, 12-21, https://doi.org/10.1016/j.atmosenv.2015.11.008, 2016.

Baker, B., Bai, J.-H., Johnson, C., Cai, Z.-T., Li, Q.-J., Wang, Y.-F., Guenther, A., Greenberg, J., Klinger, L., Geron, C., and Rasmussen, R.: Wet and dry season ecosystem level fluxes of isoprene and monoterpenes from a southeast Asian secondary forest and rubber tree plantation, Atmospheric Environment, 39, 381-390, https://doi.org/10.1016/j.atmosenv.2004.07.033, 2005.

Benjamin, M. T., Sudol, M., Vorsatz, D., and Winer, A. M.: A spatially and temporally resolved biogenic hydrocarbon emissions inventory for the California South Coast Air Basin, Atmospheric Environment, 31, 3087-3100, https://doi.org/10.1016/S1352-2310(97)00014-9, 1997.

Bonan, G. B., Oleson, K. W., Vertenstein, M., Levis, S., Zeng, X., Dai, Y., Dickinson, R. E., and Yang, Z.-L.: The Land Surface Climatology of the Community Land Model Coupled to the NCAR Community Climate Model, Journal of Climate, 15, 3123-3149, 10.1175/1520-0442(2002)015<3123:tlscot>2.0.co;2, 2002.

Bowling, D. R., Delany, A. C., Turnipseed, A. A., Baldocchi, D. D., and Monson, R. K.: Modification of the relaxed eddy accumulation technique to maximize measured scalar mixing ratio differences in updrafts and downdrafts, Journal of Geophysical Research: Atmospheres, 104, 9121-9133, 10.1029/1999jd900013, 1999.

Chen, J., Liao, A., Chen, J., Peng, S., Chen, 1., and Zhang, h.: 30-Meter Global Land Cover Data Product- Globe Land30, Geomatics World, 24, 1-8, 2017.

Fehsenfeld, F., Calvert, J., Fall, R., Goldan, P., Guenther, A. B., Hewitt, C. N., Lamb, B., Liu, S., Trainer, M., Westberg, H., and Zimmerman, P.: Emissions of volatile organic compounds from vegetation and the implications for atmospheric chemistry, Global Biogeochemical Cycles, 6, 389-430, 10.1029/92gb02125, 1992.

Fu, D., Millet, D. B., Wells, K. C., Payne, V. H., Yu, S., Guenther, A., and Eldering, A.: Direct retrieval of isoprene from satellite-based infrared measurements, Nature Communications, 10, 3811, 10.1038/s41467-019-11835-0, 2019. 
https://doi.org/10.5194/bg-2019-458

Preprint. Discussion started: 2 January 2020

(c) Author(s) 2020. CC BY 4.0 License.

Fu, T.-M., Jacob, D. J., Palmer, P. I., Chance, K., Wang, Y. X., Barletta, B., Blake, D. R., Stanton, J. C., and Pilling, M. J.: Space-based formaldehyde measurements as constraints on volatile organic compound emissions in east and south Asia and implications for ozone, Journal of Geophysical Research: Atmospheres, 112, 10.1029/2006jd007853, 2007.

Fu, Y., and Liao, H.: Simulation of the interannual variations of biogenic emissions of volatile organic compounds in China: Impacts on tropospheric ozone and secondary organic aerosol, Atmospheric Environment, 59, 170-185, https://doi.org/10.1016/j.atmosenv.2012.05.053, 2012.

Guenther, A., Hewitt, C. N., Erickson, D., Fall, R., Geron, C., Graedel, T., Harley, P., Klinger, L., Lerdau, M., Mckay, W. A., Pierce, T., Scholes, B., Steinbrecher, R., Tallamraju, R., Taylor, J., and Zimmerman, P.: A global model of natural volatile organic compound emissions, Journal of Geophysical Research: Atmospheres, 100, 8873-8892, 10.1029/94jd02950, 1995. Guenther, A., Geron, C., Pierce, T., Lamb, B., Harley, P., and Fall, R.: Natural emissions of non-methane volatile organic compounds, carbon monoxide, and oxides of nitrogen from North America, Atmospheric Environment, 34, 2205-2230, https://doi.org/10.1016/S1352-2310(99)00465-3, 2000.

Guenther, A., Karl, T., Harley, P., Wiedinmyer, C., Palmer, P. I., and Geron, C.: Estimates of global terrestrial isoprene emissions using MEGAN (Model of Emissions of Gases and Aerosols from Nature), Atmos. Chem. Phys., 6, 3181-3210, 10.5194/acp-6-3181-2006, 2006.

Guenther, A.: Biological and Chemical Diversity of Biogenic Volatile Organic Emissions into the Atmosphere, ISRN Atmospheric Sciences, 2013, 27, 10.1155/2013/786290, 2013.

Guenther, A. B., Jiang, X., Heald, C. L., Sakulyanontvittaya, T., Duhl, T., Emmons, L. K., and Wang, X.: The Model of Emissions of Gases and Aerosols from Nature version 2.1 (MEGAN2.1): an extended and updated framework for modeling biogenic emissions, Geosci. Model Dev., 5, 1471-1492, 10.5194/gmd-5-1471-2012, 2012.

Jin, J., Miller, N. L., and Schlegel, N.: Sensitivity Study of Four Land Surface Schemes in the WRF Model, Advances in Meteorology, 2010, 11, 10.1155/2010/167436, 2010.

Klinger, L. F., Li, Q.-J., Guenther, A. B., Greenberg, J. P., Baker, B., and Bai, J.-H.: Assessment of volatile organic compound emissions from ecosystems of China, Journal of Geophysical Research: Atmospheres, 107, ACH 16-11-ACH 16-21, 10.1029/2001jd001076, 2002.

Lawrence, D. M., Oleson, K. W., Flanner, M. G., Thornton, P. E., Swenson, S. C., Lawrence, P. J., Zeng, X., Yang, Z.-L., Levis, S., Sakaguchi, K., Bonan, G. B., and Slater, A. G.: Parameterization Improvements and Functional and Structural Advances in Version 4 of the Community Land Model, Journal of Advances in Modeling Earth Systems, 3, 10.1029/2011ms000045, 2011.

Levis, S., Wiedinmyer, C., Bonan, G. B., and Guenther, A.: Simulating biogenic volatile organic compound emissions in the Community Climate System Model, Journal of Geophysical Research: Atmospheres, 108, 10.1029/2002jd003203, 2003.

Li, C., Wang, J., Hu, L., Yu, L., Clinton, N., Huang, H., Yang, J., and Gong, P.: A Circa 2010 Thirty Meter Resolution Forest Map for China, Remote Sensing, 6, 5325-5343, 2014a. 
https://doi.org/10.5194/bg-2019-458

Preprint. Discussion started: 2 January 2020

(c) Author(s) 2020. CC BY 4.0 License.

Li, L. Y., Chen, Y., and Xie, S. D.: Spatio-temporal variation of biogenic volatile organic compounds emissions in China, Environmental Pollution, 182, 157-168, https://doi.org/10.1016/j.envpol.2013.06.042, 2013.

Li, M., Huang, X., Li, J., and Song, Y.: Estimation of biogenic volatile organic compound (BVOC) emissions from the terrestrial ecosystem in China using real-time remote sensing data, Atmos. Chem. Phys. Discuss., 2012, 6551-6592, 10.5194/acpd-12-6551-2012, 2012.

Li, M., Song, Y., Huang, X., Li, J., Mao, Y., Zhu, T., Cai, X., and Liu, B.: Improving mesoscale modeling using satellitederived land surface parameters in the Pearl River Delta region, China, Journal of Geophysical Research: Atmospheres, 119, 6325-6346, 10.1002/2014jd021871, 2014b.

Li, M., Mao, Z., Song, Y., Liu, M., and Huang, X.: Impacts of the Decadal Urbanization on Thermally Induced Circulations in Eastern China, Journal of Applied Meteorology and Climatology, 54, 259-282, 10.1175/jamc-d-14-0176.1, 2015. coupled regional climate model (Weather Research and Forecasting Model 3-Community Land Model 3.5), Journal of Geophysical Research: Atmospheres, 117, 10.1029/2011jd016991, 2012.

Markovic, M., Jones, C. G., Vaillancourt, P. A., Paquin, D., Winger, K., and Paquin-Ricard, D.: An evaluation of the surface radiation budget over North America for a suite of regional climate models against surface station observations, Climate Dynamics, 31, 779-794, 10.1007/s00382-008-0378-6, 2008.

Müller, J. F., Stavrakou, T., Wallens, S., De Smedt, I., Van Roozendael, M., Potosnak, M. J., Rinne, J., Munger, B., Goldstein, A., and Guenther, A. B.: Global isoprene emissions estimated using MEGAN, ECMWF analyses and a detailed canopy environment model, Atmos. Chem. Phys., 8, 1329-1341, 10.5194/acp-8-1329-2008, 2008. Oleson, K., Lawrence, D., Bonan, G. B., Flanner, M., Kluzek, E., Lawrence, P., Levis, S., Swenson, S. C., Thornton, P. E., Dai, A., Decker, M., Dickinson, R., Feddema, J., Heald, C., Hoffman, F., Lamarque, J.-F., Mahowald, N., Niu, G.-Y., Qian, T., and Zeng, X.: Technical Description of version 4.0 of the Community Land Model (CLM), 2010. concentration and vapour pressure deficit on isoprene emission from leaves of Populus deltoides during drought, Functional Plant Biology, 31, 1137-1147, https://doi.org/10.1071/FP04142, 2004. Sakulyanontvittaya, T., Duhl, T., Wiedinmyer, C., Helmig, D., Matsunaga, S., Potosnak, M., Milford, J., and Guenther, A.: Monoterpene and Sesquiterpene Emission Estimates for the United States, Environmental Science \& Technology, 42, 1623$1629,10.1021 /$ es702274e, 2008.

Sindelarova, K., Granier, C., Bouarar, I., Guenther, A., Tilmes, S., Stavrakou, T., Müller, J. F., Kuhn, U., Stefani, P., and Knorr, W.: Global data set of biogenic VOC emissions calculated by the MEGAN model over the last 30 years, Atmos. Chem. Phys., 14, 9317-9341, 10.5194/acp-14-9317-2014, 2014.

452 Situ, S., Guenther, A., Wang, X., Jiang, X., Turnipseed, A., Wu, Z., Bai, J., and Wang, X.: Impacts of seasonal and regional 453 variability in biogenic VOC emissions on surface ozone in the Pearl River delta region, China, Atmos. Chem. Phys., 13, 11803$454 \quad 11817,10.5194 / \mathrm{acp}-13-11803-2013,2013$. 
https://doi.org/10.5194/bg-2019-458

Preprint. Discussion started: 2 January 2020

(c) Author(s) 2020. CC BY 4.0 License.

\section{(c) (1)}

Situ, S., Wang, X., Guenther, A., Zhang, Y., Wang, X., Huang, M., Fan, Q., and Xiong, Z.: Uncertainties of isoprene emissions in the MEGAN model estimated for a coniferous and broad-leaved mixed forest in Southern China, Atmospheric Environment, 98, 105-110, https://doi.org/10.1016/j.atmosenv.2014.08.023, 2014.

Stavrakou, T., Müller, J. F., Bauwens, M., De Smedt, I., Van Roozendael, M., Guenther, A., Wild, M., and Xia, X.: Isoprene emissions over Asia 1979\&ndash;2012: impact of climate and land-use changes, Atmos. Chem. Phys., 14, 4587-4605, 10.5194/acp-14-4587-2014, 2014.

Tie, X., Li, G., Ying, Z., Guenther, A., and Madronich, S.: Biogenic emissions of isoprenoids and NO in China and comparison to anthropogenic emissions, Science of The Total Environment, 371, 238-251, https://doi.org/10.1016/j.scitotenv.2006.06.025, 2006.

Wang, H., Wu, Q., Liu, H., Wang, Y., Cheng, H., Wang, R., Wang, L., Xiao, H., and Yang, X.: Sensitivity of biogenic volatile organic compound emissions to leaf area index and land cover in Beijing, Atmos. Chem. Phys., 18, 9583-9596, 10.5194/acp18-9583-2018, 2018.

Wang, X., Situ, S., Chen, W., Zheng, J., Guenther, A., Fan, Q., and Chang, M.: Numerical model to quantify biogenic volatile organic compound emissions: The Pearl River Delta region as a case study, Journal of Environmental Sciences, 46, 72-82, https://doi.org/10.1016/j.jes.2015.08.032, 2016.

Wang, X. M., Situ, S. P., Guenther, A., Chen, F., Wu, Z. Y., Xia, B. C., and Wang, T. J.: Spatiotemporal variability of biogenic terpenoid emissions in Pearl River Delta, China, with high-resolution land-cover and meteorological data, Tellus Ser. B-Chem. Phys. Meteorol., 63, 241-254, 10.1111/j.1600-0889.2010.00523.x, 2011.

Wild, M.: Short-wave and long-wave surface radiation budgets in GCMs: a review based on the IPCC-AR4/CMIP3 models, Tellus A: Dynamic Meteorology and Oceanography, 60, 932-945, 10.1111/j.1600-0870.2008.00342.x, 2008.

Zeng, X., Shaikh, M., Dai, Y., Dickinson, R. E., and Myneni, R.: Coupling of the Common Land Model to the NCAR Community Climate Model, Journal of Climate, 15, 1832-1854, 10.1175/1520-0442(2002)015<1832:cotclm>2.0.co;2, 2002. Zheng, J., Zheng, Z., Yu, Y., and Zhong, L.: Temporal, spatial characteristics and uncertainty of biogenic VOC emissions in the Pearl River Delta region, China, Atmospheric Environment, 44, 1960-1969, https://doi.org/10.1016/j.atmosenv.2010.03.001, 2010.

Zhu, Z., Piao, S., Myneni, R. B., Huang, M., Zeng, Z., Canadell, J. G., Ciais, P., Sitch, S., Friedlingstein, P., Arneth, A., Cao, C., Cheng, L., Kato, E., Koven, C., Li, Y., Lian, X., Liu, Y., Liu, R., Mao, J., Pan, Y., Peng, S., Peñuelas, J., Poulter, B., Pugh, T. A. M., Stocker, B. D., Viovy, N., Wang, X., Wang, Y., Xiao, Z., Yang, H., Zaehle, S., and Zeng, N.: Greening of the Earth and its drivers, Nature Climate Change, 6, 791-795, 10.1038/nclimate3004, 2016. 
https://doi.org/10.5194/bg-2019-458

Preprint. Discussion started: 2 January 2020

(C) Author(s) 2020. CC BY 4.0 License.

Table 1 BVOC emission factors (EF, $\left.\mu \mathrm{g} \mathrm{C} \mathrm{m}^{-2} \mathrm{~h}^{-1}\right)$ for each plant functional type (PFT).

\begin{tabular}{|c|c|c|c|c|c|c|c|}
\hline PFT & NE_EV a & NE_DE ${ }^{a}$ & BR_EV a & BR_DE ${ }^{a}$ & Shrub & Grass & Crop \\
\hline $\mathrm{ISO}^{\mathrm{b}}$ & 1270.2 & 1100.0 & 3565.4 & 4638.8 & 1280 & 231.9 & 90.0 \\
\hline $\mathrm{API}^{\mathrm{b}}$ & 317.6 & 801.4 & 169.8 & 147.3 & 35.9 & 0.9 & 2.0 \\
\hline $\mathrm{BPI}^{\mathrm{b}}$ & 190.5 & 314.3 & 34.0 & 47.9 & 17.9 & 0.7 & 1.5 \\
\hline $3-\mathrm{CAR}^{\mathrm{b}}$ & 101.6 & 125.7 & 11.3 & 11.0 & 12.0 & 0.1 & 0.3 \\
\hline $\mathrm{OCI}^{\mathrm{b}}$ & 44.5 & 94.3 & 42.4 & 44.2 & 17.9 & 0.9 & 2.0 \\
\hline $\operatorname{LIM}^{\mathrm{b}}$ & 63.5 & 204.3 & 22.6 & 29.5 & 12.0 & 0.3 & 0.7 \\
\hline $\mathrm{SAB}^{\mathrm{b}}$ & 44.5 & 62.9 & 22.6 & 18.4 & 8.4 & 0.3 & 0.7 \\
\hline MYR $^{b}$ & 44.5 & 94.3 & 22.6 & 11.0 & 6.0 & 0.1 & 0.3 \\
\hline
\end{tabular}

485 a NE_EV: Needleleaf Evergreen Tree; NE_DE: Needleleaf Deciduous Tree; BR_EV: Broadleaf evergreen Tree; BR_DE: Broadleaf 486 Deciduous Tree.

487 b ISO: isoprene, API: $\alpha$-pinene, BPI: $\beta$-pinene, 3-CAR: 3-carene, OCI: ocimene, LIM: limonene, SAB: sabinene, MYR: myrcene. 
https://doi.org/10.5194/bg-2019-458

Preprint. Discussion started: 2 January 2020

(c) Author(s) 2020. CC BY 4.0 License.

Table 2 The mapping of land cover types of MODIS data (MOD12Q1) to USGS classifications and plant functional types (PFTs) used in CLM.

\begin{tabular}{|c|c|c|c|c|}
\hline \multicolumn{2}{|r|}{ MODIS } & \multicolumn{2}{|r|}{ USGS } & \multirow{2}{*}{$\begin{array}{c}\text { CLM } \\
\begin{array}{c}\text { Plant Functional Type } \\
(\text { PFT })\end{array}\end{array}$} \\
\hline Category & Land-use Description & Category & Land-use Description & \\
\hline 0 & Water & 16 & Water bodies & - \\
\hline 1 & Evergreen Needleleaf Forest & 14 & Evergreen Needleleaf forest & $\begin{array}{c}\text { Needleleaf Evergreen } \\
\text { Tree }\end{array}$ \\
\hline 2 & Evergreen Broadleaf Forest & 13 & Evergreen Broadleaf forest & Broadleaf Evergreen Tree \\
\hline 3 & Deciduous Needleleaf Forest & 12 & Deciduous Needleleaf forest & $\begin{array}{c}\text { Needleleaf Deciduous } \\
\text { Tree }\end{array}$ \\
\hline 4 & Deciduous Broadleaf Forest & 11 & Deciduous Broadleaf forest & $\begin{array}{c}\text { Broadleaf Deciduous } \\
\text { Tree }\end{array}$ \\
\hline 5 & Mixed Forest & 15 & Mixed Forest & $\begin{array}{c}\text { Broadleaf Deciduous } \\
\text { Tree }\end{array}$ \\
\hline 6 & Closed Shrubland & 8 & Shrubland & Shrub \\
\hline 7 & Open Shrubland & 9 & Mixed Shrubland/Grass & Shrub \\
\hline 8 & Woody savanna & 11 & Deciduous Broadleaf forest & $\begin{array}{c}\text { Broadleaf Deciduous } \\
\text { Tree }\end{array}$ \\
\hline 9 & Savanna & 10 & Savanna & Shrub \\
\hline 10 & Grassland & 7 & Grassland & Grass \\
\hline 11 & Permanent wetland & 17 & Herb. Wetland & - \\
\hline 12 & Cropland & 5 & Crop/Grass Mosaic & Crop \\
\hline 13 & Urban and Built-up & 1 & Urban & - \\
\hline 14 & $\begin{array}{c}\text { Cropland/Natural Vegetation } \\
\text { Mosaic }\end{array}$ & 6 & Crop/Wood Mosaic & Crop \\
\hline 15 & Snow and Ice & 24 & Snow or Ice & - \\
\hline 16 & Barren or Sparsely Vegetated & 19 & Barren or Sparsely Vegetated & - \\
\hline 254 & Unclassified & 25 & No Data & - \\
\hline
\end{tabular}


https://doi.org/10.5194/bg-2019-458

Preprint. Discussion started: 2 January 2020

(C) Author(s) 2020. CC BY 4.0 License.

491 Table 3 Verification statistics of temperature at $\mathbf{2} \mathbf{m}$ height (T2) and downward shortwave radiation (SWDOWN).

\begin{tabular}{|c|c|c|c|c|c|c|c|}
\hline \multirow{2}{*}{ Variable } & \multirow{2}{*}{ Season } & \multicolumn{2}{|c|}{ Mean } & \multirow{2}{*}{$\mathrm{ME}^{\mathrm{b}}$} & \multirow{2}{*}{$\mathrm{MB}^{\mathrm{b}}$} & \multirow{2}{*}{$r^{b}$} & \multirow{2}{*}{ RMSE $^{b}$} \\
\hline & & Obs. ${ }^{a}$ & Sim. ${ }^{a}$ & & & & \\
\hline \multirow{5}{*}{$\mathrm{T} 2\left({ }^{\circ} \mathrm{C}\right)$} & Spring & 13.99 & 13.95 & 1.54 & -0.04 & 0.95 & 2.26 \\
\hline & Summer & 23.60 & 23.65 & 1.64 & 0.05 & 0.60 & 2.54 \\
\hline & Autumn & 12.70 & 12.10 & 1.47 & -0.60 & 0.96 & 2.16 \\
\hline & Winter & -1.34 & -2.84 & 2.17 & -1.50 & 0.97 & 3.00 \\
\hline & Year & 12.23 & 11.70 & 1.70 & -0.52 & 0.98 & 2.51 \\
\hline \multirow{5}{*}{$\begin{array}{l}\text { SWDOWN } \\
\left(\mathrm{W} \mathrm{m}^{-2}\right)\end{array}$} & Spring & 176.39 & 261.75 & 85.98 & 85.37 & 0.64 & 90.40 \\
\hline & Summer & 192.25 & 278.29 & 86.50 & 86.05 & 0.59 & 92.00 \\
\hline & Autumn & 129.03 & 184.58 & 57.86 & 55.55 & 0.59 & 61.89 \\
\hline & Winter & 92.04 & 144.36 & 53.69 & 52.32 & 0.71 & 57.60 \\
\hline & Year & 147.43 & 217.25 & 71.01 & 69.82 & 0.86 & 77.11 \\
\hline
\end{tabular}

${ }^{a}$ Obs.: Mean observed value, Sim.: Mean simulated value;

${ }^{\mathrm{b}}$ ME: Mean Error, MB: Mean Bias, $r$ : correlation coefficient, RMSE: Root Mean Square Error. 
https://doi.org/10.5194/bg-2019-458

Preprint. Discussion started: 2 January 2020

(c) Author(s) 2020. CC BY 4.0 License.

Table 4 Province-specific estimated BVOC emission budgets (Gg C).

\begin{tabular}{|c|c|c|c|c|c|c|c|c|c|c|}
\hline \multirow{2}{*}{ Region/Province } & \multirow{2}{*}{$\mathrm{ISO}^{\mathrm{a}}$} & \multicolumn{8}{|c|}{$\mathrm{MT}^{\mathrm{b}}$} & \multirow{2}{*}{ T_Pro } \\
\hline & & $\mathrm{API}^{\mathrm{a}}$ & $\mathrm{BPI}^{\mathrm{a}}$ & $3-\mathrm{CAR}^{\mathrm{a}}$ & $\mathrm{OCI}^{\mathrm{a}}$ & $\operatorname{LIM}^{\mathrm{a}}$ & $\mathrm{SAB}^{\mathrm{a}}$ & MYR $^{a}$ & $\bar{T}$ T_MT $^{\mathrm{c}}$ & \\
\hline Northwest & 581.4 & 55.4 & 30.6 & 8.3 & 13.7 & 18.6 & 7.6 & 4.5 & 138.7 & 720.1 \\
\hline Xinjiang & 33.2 & 1.3 & 1.1 & 0.5 & 0.7 & 0.6 & 0.3 & 0.2 & 4.7 & 37.9 \\
\hline Gansu & 93.1 & 8.5 & 5.0 & 1.6 & 2.1 & 3.1 & 1.2 & 0.8 & 22.3 & 115.4 \\
\hline Ningxia & 3.4 & 0.1 & 0.1 & 0.0 & 0.1 & 0.0 & 0.0 & 0.0 & 0.4 & 3.8 \\
\hline Qinghai & 9.7 & 0.3 & 0.3 & 0.1 & 0.2 & 0.1 & 0.1 & 0.0 & 1.0 & 10.7 \\
\hline Shaanxi & 441.9 & 45.2 & 24.0 & 6.2 & 10.7 & 14.8 & 5.9 & 3.6 & 110.3 & 552.2 \\
\hline Northeast & 1062.4 & 181.9 & 105.7 & 32.2 & 37.9 & 65.8 & 22.9 & 16.3 & 462.6 & 1525.0 \\
\hline Inner Mongolia & 229.6 & 65.7 & 38.9 & 13.5 & 12.0 & 24.5 & 7.7 & 6.6 & 168.8 & 398.4 \\
\hline Heilongjiang & 438.3 & 75.8 & 43.6 & 12.5 & 16.5 & 27.1 & 9.8 & 6.4 & 191.7 & 630.0 \\
\hline Jilin & 247.8 & 26.6 & 15.0 & 3.6 & 5.9 & 9.2 & 3.4 & 2.0 & 65.9 & 313.7 \\
\hline Liaoning & 146.7 & 13.8 & 8.2 & 2.5 & 3.4 & 5.0 & 2.0 & 1.2 & 36.2 & 182.9 \\
\hline North & 418.3 & 44.1 & 26.3 & 10.7 & 13.9 & 16.1 & 7.5 & 4.7 & 123.1 & 541.4 \\
\hline Beijing & 32.8 & 2.8 & 1.6 & 0.7 & 0.8 & 1.0 & 0.5 & 0.3 & 7.8 & 40.6 \\
\hline Shanxi & 92.9 & 11.4 & 6.6 & 2.6 & 3.3 & 4.1 & 1.8 & 1.2 & 31.0 & 124.0 \\
\hline Hebei & 132.2 & 10.6 & 6.8 & 3.2 & 3.6 & 4.2 & 2.0 & 1.3 & 31.7 & 163.9 \\
\hline Shandong & 14.9 & 1.2 & 1.1 & 0.6 & 0.8 & 0.5 & 0.3 & 0.2 & 4.6 & 19.5 \\
\hline Tianjin & 1.0 & 0.1 & 0.1 & 0.0 & 0.0 & 0.0 & 0.0 & 0.0 & 0.3 & 1.3 \\
\hline Henan & 144.5 & 18.0 & 10.1 & 3.6 & 5.3 & 6.1 & 2.8 & 1.7 & 47.6 & 192.1 \\
\hline Central & 3048.2 & 282.9 & 153.4 & 52.3 & 69.8 & 93.4 & 40.5 & 27.2 & 719.5 & 3767.7 \\
\hline Hubei & 698.3 & 65.8 & 35.1 & 10.7 & 16.7 & 21.8 & 9.2 & 5.7 & 164.9 & 863.2 \\
\hline Anhui & 305.8 & 27.0 & 15.4 & 5.2 & 6.8 & 9.0 & 3.9 & 2.5 & 69.7 & 375.5 \\
\hline Hunan & 1100.0 & 101.9 & 55.9 & 18.8 & 25.2 & 34.1 & 14.5 & 9.6 & 260.1 & 1360.1 \\
\hline Jiangxi & 944.1 & 88.2 & 47.1 & 17.6 & 21.1 & 28.5 & 12.9 & 9.5 & 224.8 & 1168.9 \\
\hline Southwest & 4063.6 & 433.8 & 249.0 & 93.5 & 104.0 & 151.7 & 64.4 & 45.5 & 1141.9 & 5205.5 \\
\hline Tibet & 134.5 & 20.5 & 12.1 & 4.7 & 3.5 & 6.4 & 2.8 & 2.5 & 52.45 & 187.0 \\
\hline Sichuan & 691.0 & 69.1 & 43.0 & 15.9 & 17.0 & 25.7 & 10.3 & 6.8 & 187.6 & 878.6 \\
\hline Chongqing & 261.0 & 25.8 & 14.8 & 5.0 & 6.5 & 9.1 & 3.7 & 2.4 & 67.4 & 328.4 \\
\hline Yunnan & 1092.0 & 133.3 & 77.6 & 29.8 & 30.3 & 46.0 & 19.6 & 14.4 & 351.0 & 1443.0 \\
\hline Guizhou & 536.1 & 55.0 & 32.2 & 11.8 & 14.2 & 20.3 & 8.3 & 5.4 & 147.2 & 683.3 \\
\hline
\end{tabular}


https://doi.org/10.5194/bg-2019-458

Preprint. Discussion started: 2 January 2020

(c) Author(s) 2020. CC BY 4.0 License.

Table 4 Continued.

\begin{tabular}{lllllllllll}
\hline \multirow{2}{*}{ Region/Province } & \multirow{2}{*}{ ISO $^{\mathrm{a}}$} & \multicolumn{7}{c}{$\mathrm{MT}^{\mathrm{b}}$} & & \\
\cline { 3 - 8 } & & API $^{\mathrm{a}}$ & BPI $^{\mathrm{a}}$ & $3-\mathrm{CAR}^{\mathrm{a}}$ & OCI $^{\mathrm{a}}$ & LIM $^{\mathrm{a}}$ & SAB $^{\mathrm{a}}$ & MYR $^{\mathrm{a}}$ & T_MT $^{\mathrm{c}}$ & \\
\hline Guangxi & 1349.0 & 130.1 & 69.3 & 26.3 & 32.6 & 44.2 & 19.7 & 14.1 & 336.3 & 1685.3 \\
Southeast & $\mathbf{2 3 5 3 . 9}$ & $\mathbf{2 4 1 . 5}$ & $\mathbf{1 2 6 . 1}$ & $\mathbf{4 5 . 3}$ & $\mathbf{5 5 . 5}$ & $\mathbf{7 8 . 1}$ & $\mathbf{3 4 . 9}$ & $\mathbf{2 6 . 1}$ & $\mathbf{6 0 7 . 4}$ & $\mathbf{2 9 6 1 . 3}$ \\
Jiangsu & 39.2 & 2.7 & 1.9 & 1.2 & 1.2 & 1.2 & 0.6 & 0.4 & 9.2 & 48.4 \\
Shanghai & 1.0 & 0.1 & 0.0 & 0.0 & 0.0 & 0.0 & 0.0 & 0.0 & 0.2 & 1.2 \\
Zhejiang & 402.9 & 44.6 & 26.3 & 8.9 & 9.5 & 14.8 & 6.0 & 4.2 & 114.3 & 517.2 \\
Fujian & 629.0 & 65.7 & 32.6 & 9.9 & 14.0 & 20.4 & 8.9 & 6.7 & 158.1 & 787.1 \\
Guangdong & 879.6 & 87.2 & 45.3 & 18.0 & 21.4 & 29.1 & 13.4 & 10.1 & 224.4 & 1104.0 \\
Macao & 1.4 & 0.2 & 0.1 & 0.0 & 0.0 & 0.0 & 0.0 & 0.0 & 0.4 & 1.8 \\
Hong Kong & 1.1 & 0.1 & 0.1 & 0.0 & 0.0 & 0.0 & 0.0 & 0.0 & 0.3 & 1.4 \\
Hainan & 285.8 & 27.0 & 13.5 & 5.0 & 6.8 & 8.6 & 4.0 & 2.9 & 67.7 & 353.5 \\
Taiwan & 113.9 & 13.9 & 6.4 & 2.3 & 2.5 & 3.9 & 1.9 & 1.8 & 32.8 & 146.7 \\
\hline Nation & 11528 & 1240 & 691 & 242 & 295 & 424 & 178 & 124 & 3193 & 14721 \\
\hline
\end{tabular}

${ }^{\text {a }}$ Refer to Table 1;

${ }^{\mathrm{b}}$ MT: Monoterpenes;

${ }^{\mathrm{c}} \mathrm{T}$ _MT: Regional or provincial monoterpene totals, T_Pro: Regional or provincial BVOC totals, including isoprene and monoterpenes. 
https://doi.org/10.5194/bg-2019-458

Preprint. Discussion started: 2 January 2020

(C) Author(s) 2020. CC BY 4.0 License.

Table 5 The BVOC emission budgets of each plant functional type (PFTs) (Gg C).

\begin{tabular}{|c|c|c|c|c|c|c|c|c|c|c|}
\hline \multirow{2}{*}{ PFTs } & \multirow{2}{*}{$\mathrm{ISO}^{\mathrm{a}}$} & \multicolumn{8}{|c|}{$\mathrm{MT}^{\mathrm{a}}$} & \multirow{2}{*}{ T_ALL ${ }^{b}$} \\
\hline & & $\mathrm{API}^{\mathrm{a}}$ & $\mathrm{BPI}^{\mathrm{a}}$ & $3-\mathrm{CAR}^{\mathrm{a}}$ & $\mathrm{OCI}^{\mathrm{a}}$ & $\operatorname{LIM}^{\mathrm{a}}$ & $\mathrm{SAB}^{\mathrm{a}}$ & MYR $^{a}$ & $\mathrm{~T}_{\mathrm{T}} \mathrm{MT}^{\mathrm{b}}$ & \\
\hline NE_EV ${ }^{a}$ & 59.3 & 35.6 & 38.6 & 20.6 & 3.4 & 12.9 & 5.0 & 5.0 & 121.0 & 180.3 \\
\hline NE_DE ${ }^{a}$ & 4.2 & 33.7 & 20.0 & 8.0 & 3.0 & 13.0 & 2.6 & 4.0 & 84.4 & 88.6 \\
\hline BR_EV ${ }^{a}$ & 1421.0 & 169.0 & 61.6 & 20.5 & 28.8 & 41.0 & 22.5 & 22.5 & 365.8 & 1786.8 \\
\hline BR_DE ${ }^{a}$ & 7442.0 & 806.6 & 426.0 & 97.8 & 179.7 & 262.4 & 100.8 & 60.2 & 1934.0 & 9376.0 \\
\hline Shrub & 2295.0 & 183.3 & 132.7 & 89.0 & 70.9 & 89.0 & 42.9 & 30.6 & 638.3 & 2933.3 \\
\hline Grass & 188.1 & 2.2 & 2.2 & 0.3 & 1.8 & 1.0 & 0.7 & 0.2 & 8.4 & 196.5 \\
\hline Crop & 119.4 & 9.2 & 9.9 & 2.0 & 7.4 & 4.6 & 3.2 & 1.4 & 37.8 & 157.2 \\
\hline
\end{tabular}

$501 \quad$ a: Refer to Table 1;

b: T_MT: Total monoterpenes emission budget of each PFT, T_ALL: Total BVOC emission budget of each PFT, including isoprene and 503 monoterpenes. 
https://doi.org/10.5194/bg-2019-458

Preprint. Discussion started: 2 January 2020

(C) Author(s) 2020. CC BY 4.0 License.

504 Table 6 Comparisons of the estimated BVOC budgets $\left(\mathrm{Tg} \mathrm{C}_{\mathbf{~} \mathbf{r}^{-1}}\right)$ with previous studies

\begin{tabular}{ccccl}
\hline \multirow{2}{*}{ Base year } & \multicolumn{3}{c}{ Emission Budget } & \multicolumn{1}{c}{ Reference } \\
\cline { 2 - 4 } & ISO $^{\mathrm{a}}$ & MT $^{\mathrm{a}}$ & Total & \\
\hline 2018 & 11.5 & 3.2 & 14.7 & This study Guenther et al. (1995) $^{\mathrm{a}}$ \\
- & 15.0 & 4.3 & 19.3 & Klinger et al. (2002) $^{\mathrm{a}}$ \\
- & 4.1 & 3.5 & 7.6 & Tie et al. (2006) $^{\mathrm{b}}$ \\
2004 & 6.8 & 2.8 & 9.6 & Guenther et al. (2006) $^{\mathrm{c}}$ \\
2000 & 10.0 & 2.5 & 12.5 & Fu and Liao (2012) $^{\mathrm{c}}$ \\
Averaged over 2001- & 9.6 & 2.8 & 12.4 & Fu et al. (2007) $^{\mathrm{d}}$ \\
2006 & 12.7 & & & Stavrakou et al. (2014) $^{\mathrm{d}}$ \\
- & 5.7 & & &
\end{tabular}

a: Based on G95 algorithms (Guenther et al., 1995);

b: Based on G20 algorithms (Guenther et al., 2000);

c: Based on MEGAN2.0 algorithms (Guenther et al., 2006);

d: Top-down annual emission estimates which were inferred by inversion of GOME formaldehyde columns. 
https://doi.org/10.5194/bg-2019-458

Preprint. Discussion started: 2 January 2020

(c) Author(s) 2020. CC BY 4.0 License.

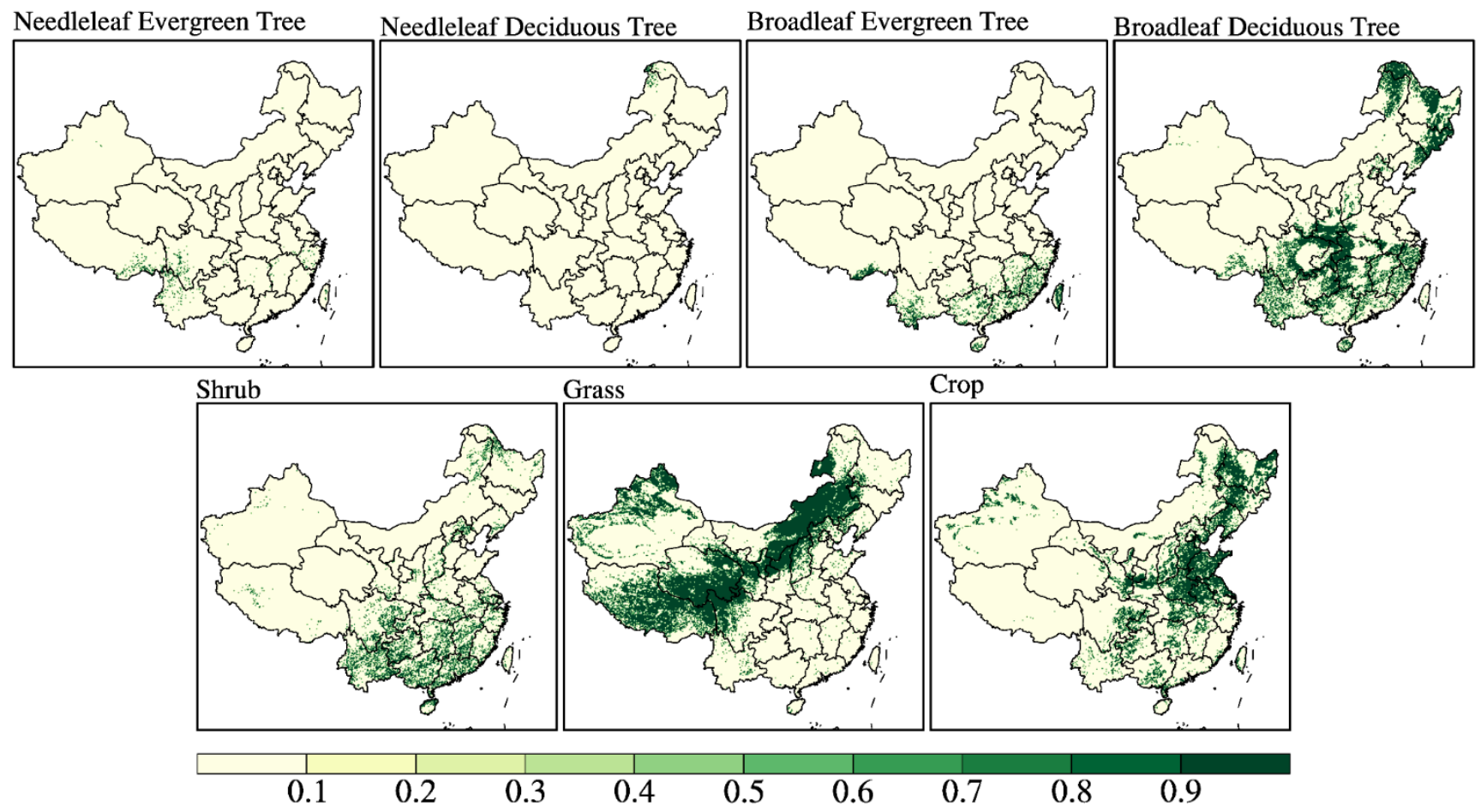

Figure 1 Spatial distribution of dominant plant functional types (PFTs) in China. 
https://doi.org/10.5194/bg-2019-458

Preprint. Discussion started: 2 January 2020

(c) Author(s) 2020. CC BY 4.0 License.

Spring
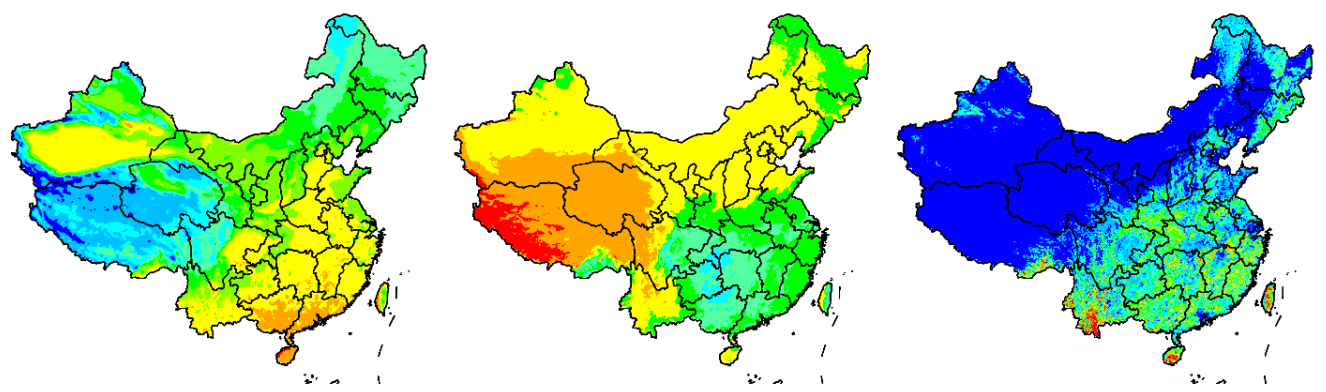

Summer
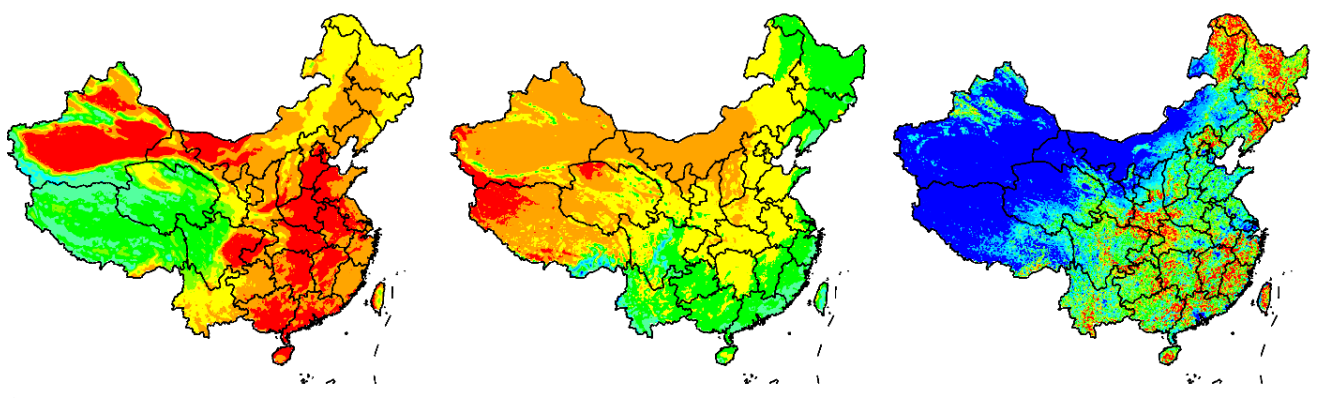

Autumn
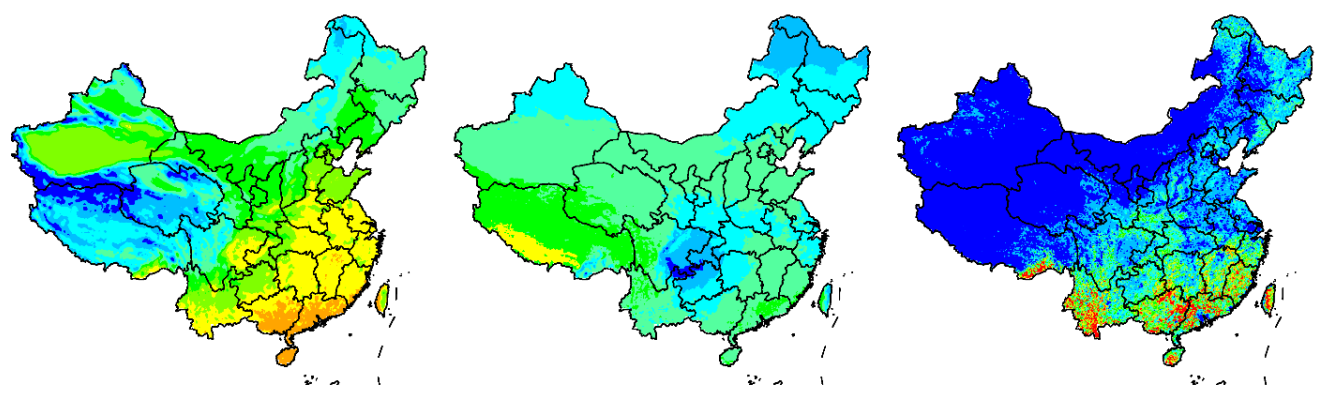

Winter
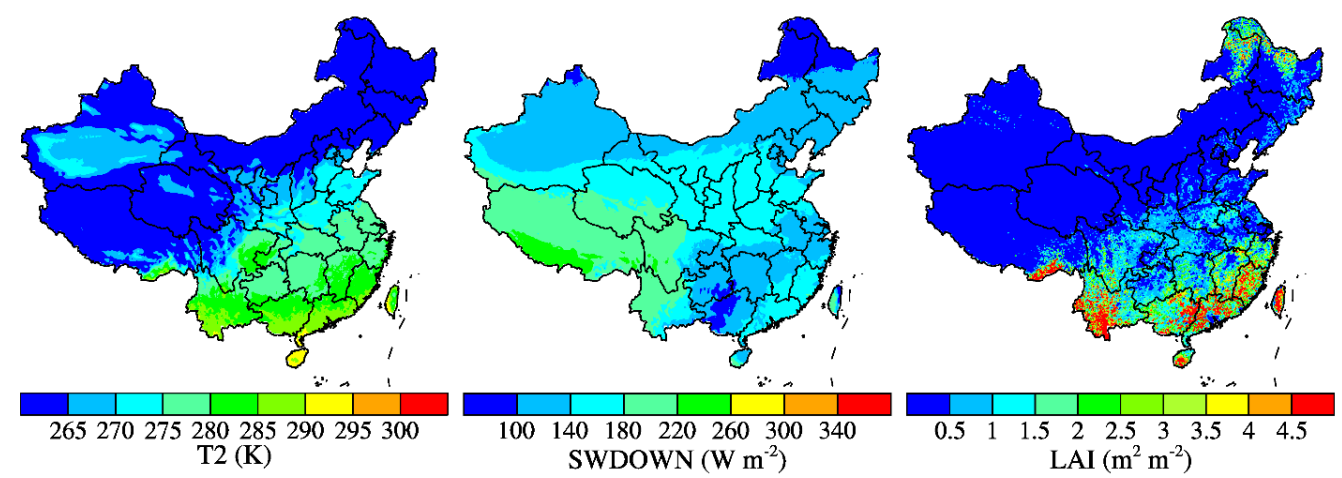

Figure 2 Season-averaged simulated air temperature at $2 \mathrm{~m}$ (T2) (middle panel) and LAI distributions (right panel) in China. 
https://doi.org/10.5194/bg-2019-458

Preprint. Discussion started: 2 January 2020

(c) Author(s) 2020. CC BY 4.0 License.
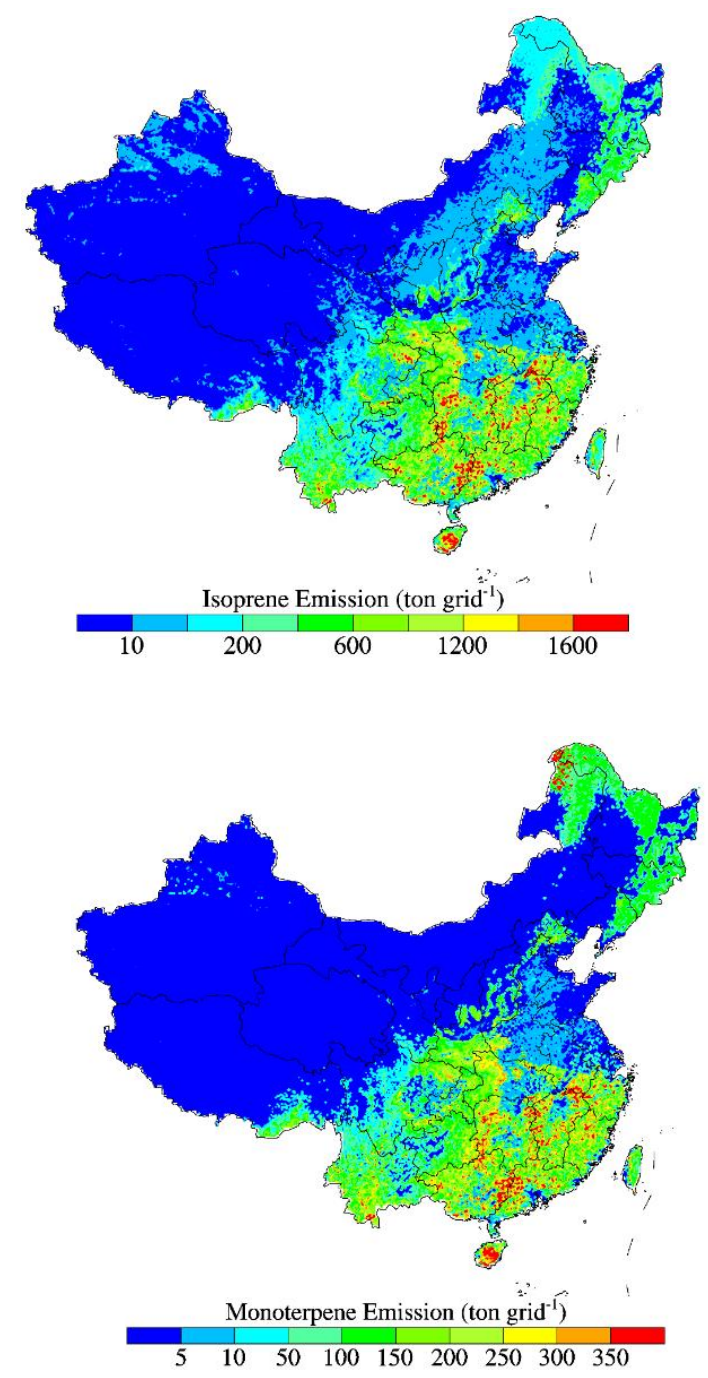

516 Figure 3 Spatial distribution of isoprene and monoterpenes emissions in the year 2018. 
(a)

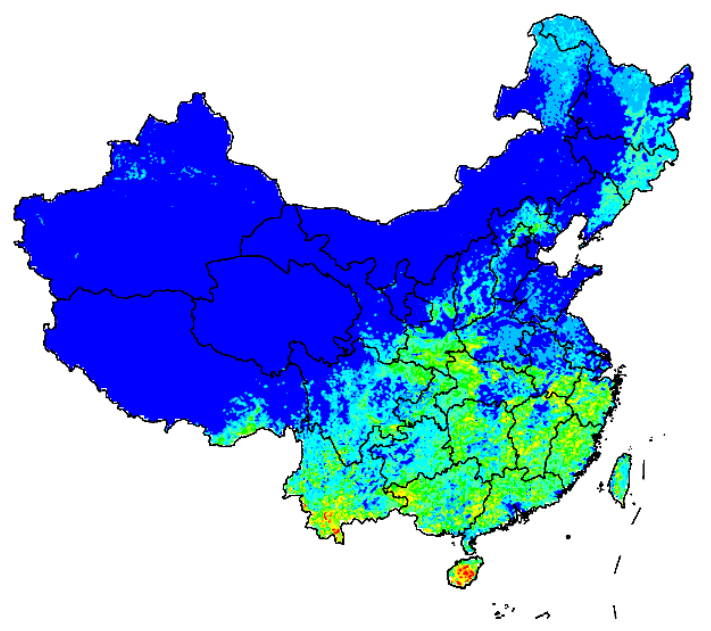

(c)

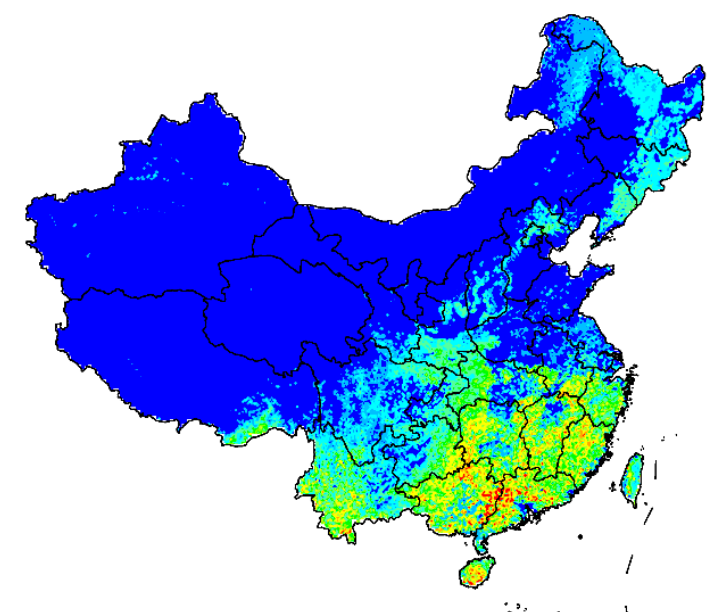

(b)

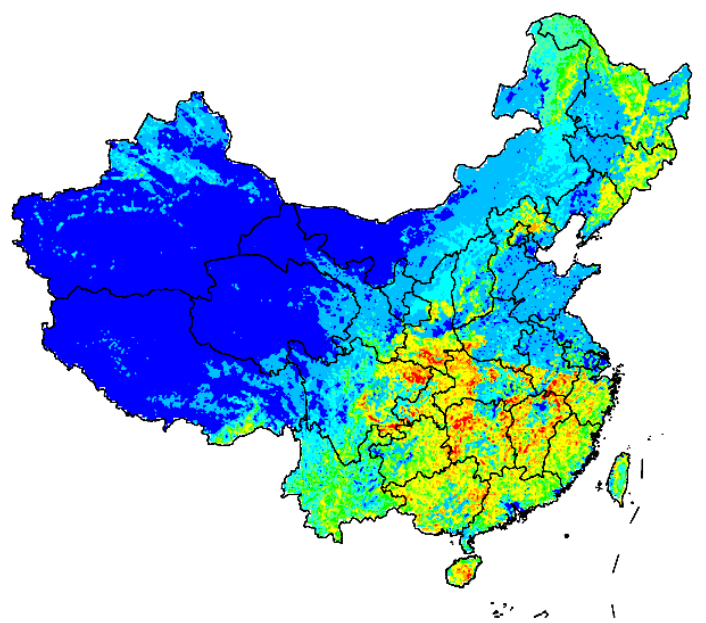

(d)

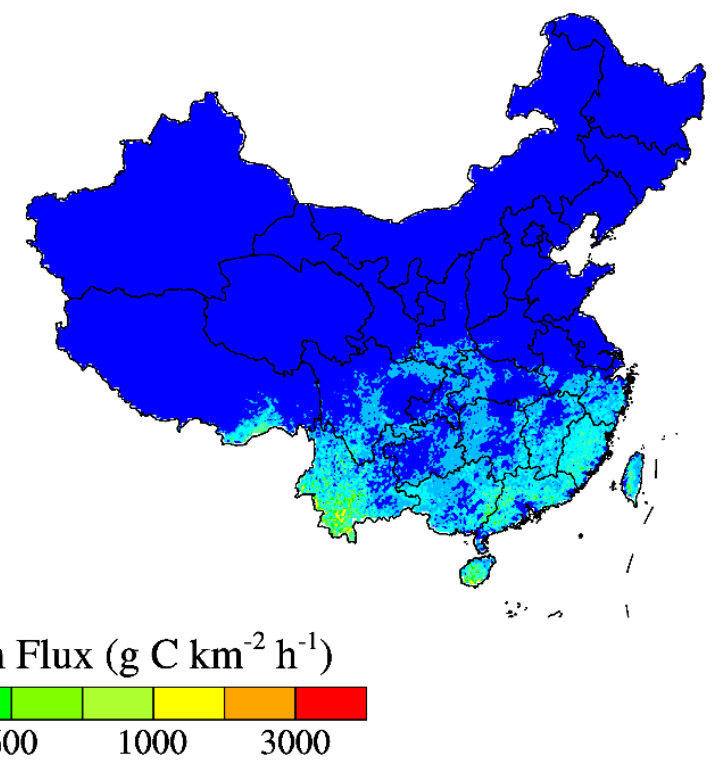

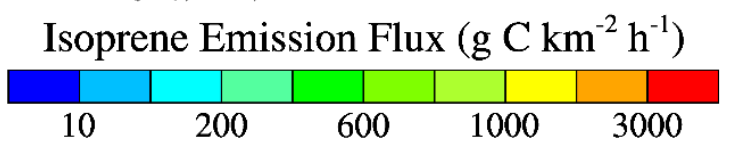

518 Figure 4 Average seasonal isoprene emission fluxes $\left(\mathrm{g} \mathrm{C} \mathrm{km}^{-2} \mathbf{h}^{-1}\right)$ : (a) spring; (b) summer; (c) autumn; (d) winter. 
(a)

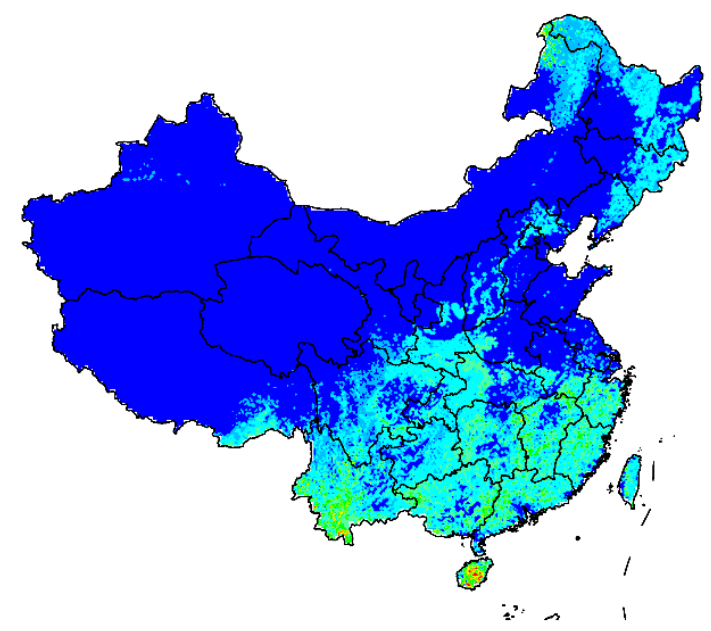

(c)

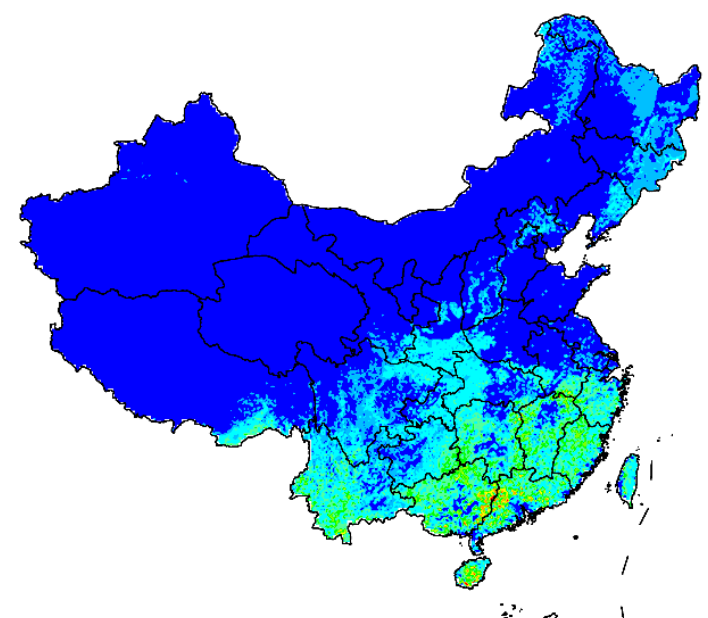

(b)

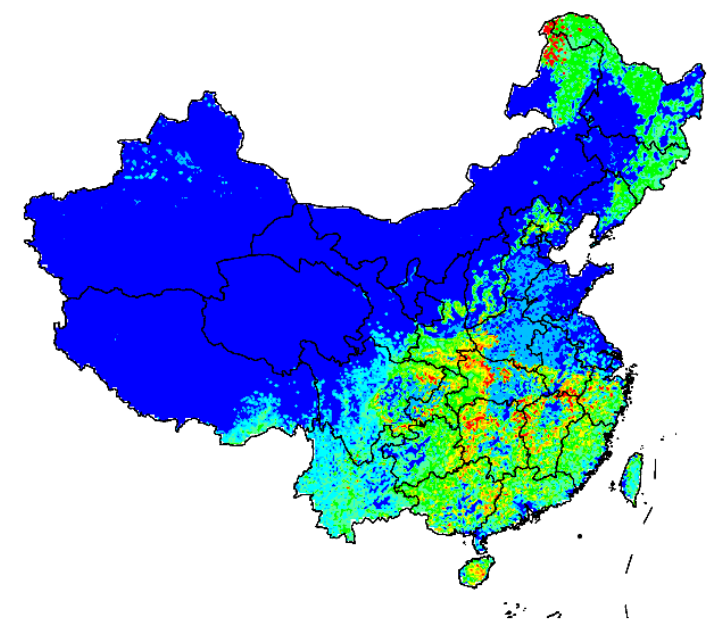

(d)

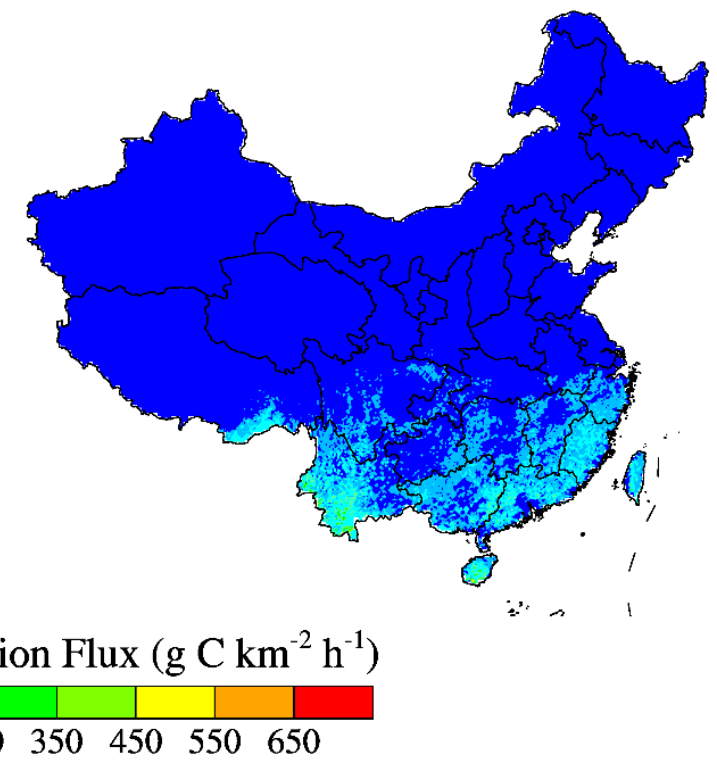

Monoterpene Emission Flux $\left(\mathrm{g} \mathrm{C} \mathrm{km}^{-2} \mathrm{~h}^{-1}\right)$

Figure 5 Average seasonal monoterpene emission fluxes $\left(\mathrm{g} \mathrm{C} \mathrm{km}^{-2} \mathrm{~h}^{-1}\right)$ : (a) spring; (b) summer; (c) autumn; (d) winter. 


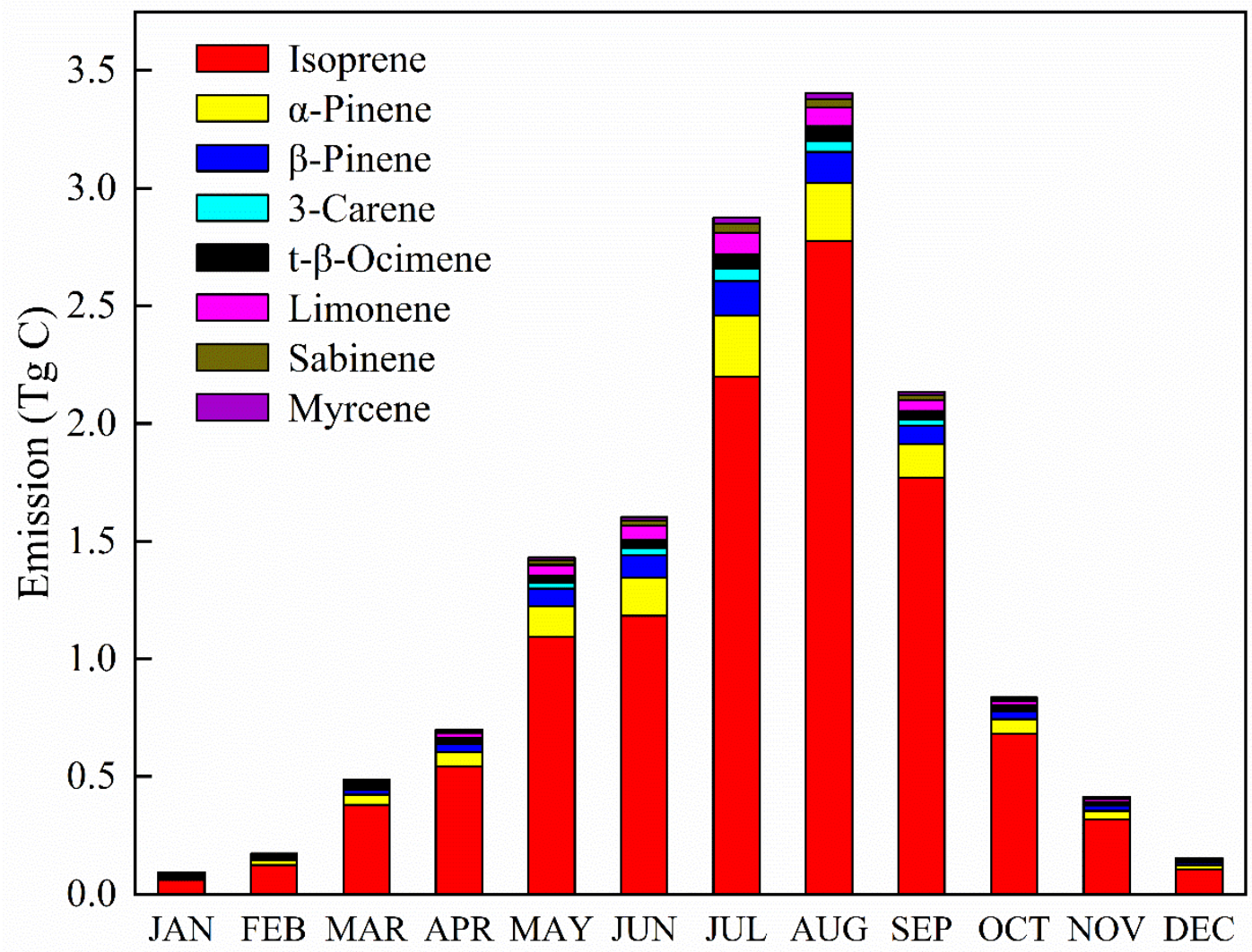

522 Figure 6 Calculated monthly variation of BVOC emission budget (Tg C). 
https://doi.org/10.5194/bg-2019-458

Preprint. Discussion started: 2 January 2020

(c) Author(s) 2020. CC BY 4.0 License.

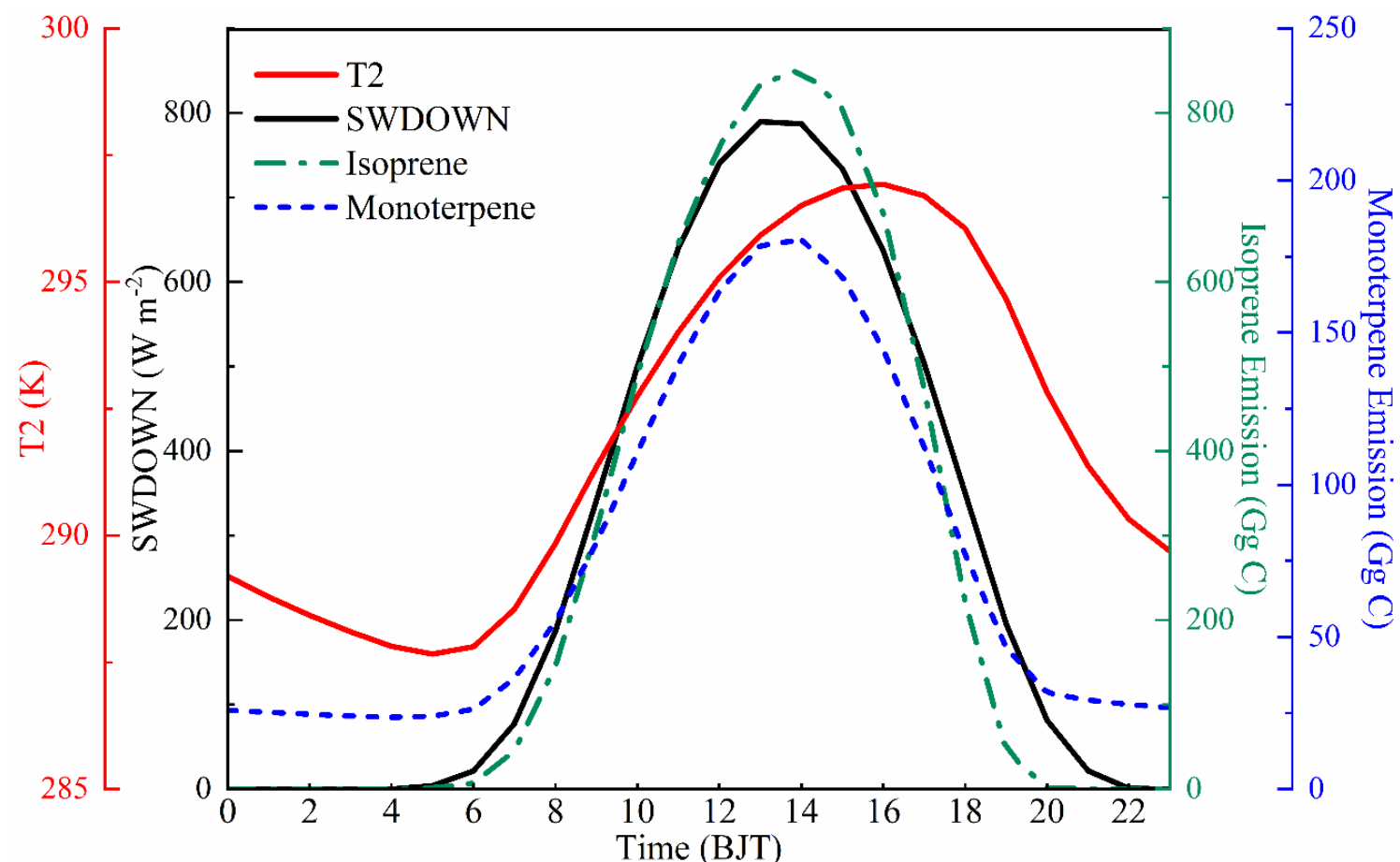

Figure 7 Diurnal variations in summer of temperature at $2 \mathrm{~m}$ height (T2), downward solar radiation (SWDOWN) and emissions of isoprene and monoterpenes (Gg C); BJT: Beijing Time. 